\title{
Occupational Cement Dust Exposure and Inflammatory Nemesis: Bangladesh Relevance
}

\author{
Rahnuma Ahmad (D) \\ Qazi Shamima Akhter $\mathbb{D}^{2}$ \\ Mainul Haque (iD) ${ }^{3}$ \\ 'Department of Physiology, Medical \\ College for Women and Hospital, Dhaka, \\ Bangladesh; ${ }^{2}$ Department of Physiology, \\ Dhaka Medical College, Dhaka, \\ Bangladesh; ${ }^{3}$ The Unit of Pharmacology, \\ Faculty of Medicine and Defence Health, \\ Universiti Pertahanan Nasional Malaysia \\ (National Defence University of \\ Malaysia), Kem Perdana Sungai Besi, \\ 57000, Kuala Lumpur, Malaysia
}

Background: Prolonged, repeated exposure to cement dust, depending on duration and sensitivity of cement dust-exposed workers, may cause deteriorating effects on the skin, eye, respiratory and hematological system. Toxic cement dust causes inflammatory damage to different body organs. White blood cells (WBCs) are considered cellular markers of ongoing tissue inflammation.

Aim of the Study: Determining the influence of occupational cement dust exposure on WBCs with its differentials (inflammatory markers) in workers from the cement manufacturing plant.

Methodology: Ninety-two seemingly healthy male subjects (46 workers of cement plant and 46 control subjects, who do not contact cement dust, residing in Dhaka) aged between 20 and 50 years participated in this cross-sectional study. This study took place in Dhaka Medical College, Bangladesh, between the years of 2017 and 2018. An automated hematoanalyser was used to assess both the total and differential count of WBC. Data were analyzed with multivariate regression analysis, independent samples $t$-test, and correlation test.

Results: The total WBC count, differential count of lymphocyte, and eosinophil were significantly $(p<0.05)$ higher in cement dust-exposed recruits than in the control group. Additionally, multivariate regression analysis revealed that duration of cement dust exposure showed a significant association with total WBC count [odds ratio $(\mathrm{OR})=4.42,95 \%$, confidence level (CI) $1.56,12.47, p$ 0.005]. Furthermore, univariate analysis revealed that the control group (not exposed to cement dust) was less likely to have the total WBC count alteration ( $\mathrm{OR}=0.122,95 \% \mathrm{CI}=0.047$ to 0.311$)$ than the cement dust-exposed group. The total WBC count showed a significant positive correlation with exposure duration to this toxic dust.

Conclusion: Cement dust exposure causes harmful inflammatory responses, as evidenced by increased total and differential WBC count. The period of contact with this toxic dust has an impact on WBC count.

Keywords: cement dust, occupational health, inflammatory response, hazard, workers, exposure, WBC count, biomarkers, Bangladesh, pollution, hematological system, early detection

\section{Introduction}

The cement industry is a fast-growing globally, and in Bangladesh. ${ }^{1}$ There has been a boost in the developing market due to sustained construction activity levels, which has led to increased demand for cement. ${ }^{1-3}$ The cement industry is a source of environmental pollution. ${ }^{4}$ In the various stages of cement production, dust and particulate matter are released. ${ }^{5,6}$ Occupational exposures to airborne particulates are estimated to cause $16 \%$ of deaths per year throughout the world due to chronic
The Unit of Pharmacology, Faculty of Medicine and Defence Health, Universiti Pertahanan Nasional Malaysia (National Defence University of Malaysia), Kem Perdana Sungai Besi, Kuala Lumpur, 57000, Malaysia

Tel +60109265543

Email runurono@gmail.com 
obstructive pulmonary disease (COPD). Additionally, approximately 519,100 deaths in 2016 result from exposure to silica, coal dust, and asbestos annually across the globe. ${ }^{7,8}$

\section{Cement Dust}

Cement dust is an example of mineral dust that constitutes chemical components like silicon, calcium, aluminum, chromium, iron. ${ }^{9-11}$ This dust is generated in different sections where cement production and processing occur, such as extraction of raw material, crusher, rotary kiln, cranes, mills, storage silos, packing area, etc. (Figure 1). ${ }^{12,13}$ Crystalline silica is a component of cement dust. ${ }^{11}$ Quartz is the most common form of crystalline silica, and on the surface of the earth, it is the second most common mineral. Almost every type of rock contains quartz, ie, igneous, metamorphic and sedimentary. ${ }^{14}$

Respirable crystalline silica dust or quartz (smaller than sand found in beaches and pollen) is released into the air during the high-energy cutting, drilling, or grinding stone, rock, concrete, and mortar processes. ${ }^{15}$ Breathing in silica dust can have damaging effects on human health. Around 23,000,00 working people in the USA alone are coming in contact with quartz in their workplace. ${ }^{16}$ Some of the harmful effects of respirable crystalline silica include silicosis, chronic respiratory illness like COPD, emphysema, lung carcinoma, pulmonary tuberculosis, small vessel vasculitis, Rheumatoid arthritis, systemic lupus erythematosus (SLE), scleroderma. Chronic exposure to crystalline silica may result in lung cancer and kidney damage. ${ }^{16-18}$

Another heavy metal present in cement dust is Chromium. ${ }^{9}$ Chromium (Cr) is a naturally occurring element present in the environment. Many compounds consist of the different oxidant states of chromium, Cr II- Cr IV. Next to the Cr III compound, chromium in the hexavalent form is most stable. ${ }^{19,20}$ Chromium metal and chromates are produced using the naturally occurring Chromium(III).

On the other hand, chromium in the hexavalent state (CrIV) is formed during industrial activities. ${ }^{21} \mathrm{~A}$ study carried out in Slovakia in 2018 regarding $\mathrm{Cr}$ (VI) content in cement found that it was about 0.2 to $3.2 \mathrm{mg} / \mathrm{kg}{ }^{22}$ $\mathrm{Cr}(\mathrm{VI})$ differs from $\mathrm{Cr}(\mathrm{III})$ in its chemistry and toxic properties. Cr (III) may play a role in glucose and lipid metabolism, whereas the very toxic Cr (VI) aggravates DNA damage, chromosomal aberrations. Chromium enters the human body through inhalation, ingestion, and dermal contact. $^{21,23}$ Repeated exposures to Cr (VI) compounds may cause abnormalities in hematological parameters, gastrointestinal system, and have potential to cause lung cancer. $^{24}$

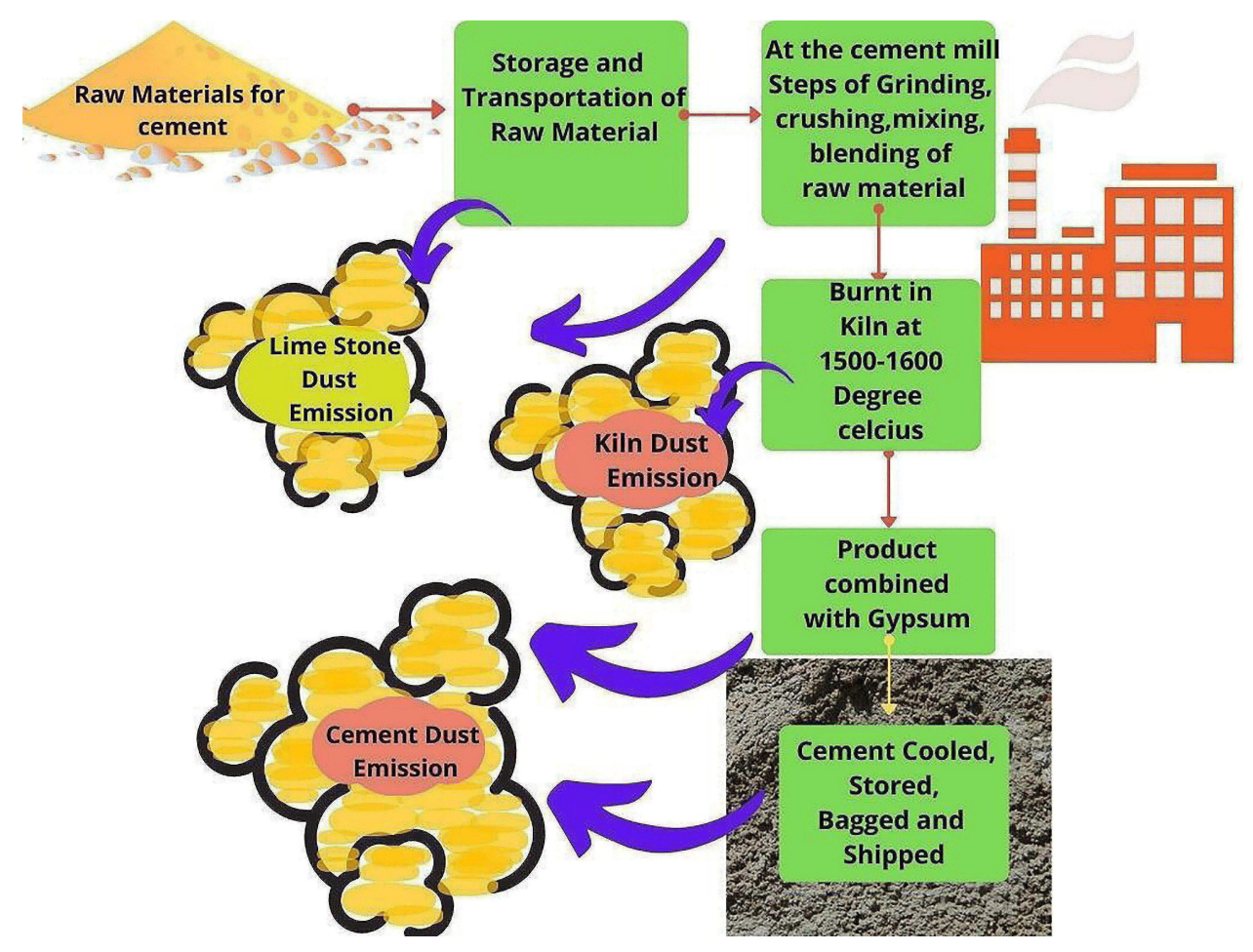

Figure I Dust emission during the different steps of cement dust production. 
Cement dust may enter the human body through the respiratory system and Gastrointestinal system and produce adverse effects. ${ }^{25}$ Occupational Crystalline Silica exposure results in inflammation in the respiratory system, leading to abnormal tissue repair, disorder, and demise. ${ }^{26}$ Hundreds of thousands of people are working daily in surroundings that are dusty and are at risk of developing occupational diseases. ${ }^{27}$

\section{Inflammatory Response}

In the human body, inflammation acts as a defense mechanism in which cells and molecules of the immune system form network to eradicate pathogenic substances and protect the body. However, excessive and long-term inflammations may result in tissue damage due to an imbalance of immunocytes and molecules. ${ }^{28}$ The response to inflammation is the activation of the signaling pathway, leading to the regulation of inflammatory mediators in local cells of the tissue and inflammatory cells recruitment from the blood. ${ }^{29}$

\section{Signaling Pathway of Inflammation}

Signals that arise during tissue damage are dangerassociated molecular patterns (DAMPs), leading to induction of biochemical changes and eventual release of NFkB. ${ }^{30}$ DAMP transmission occurs via Toll-like receptors (TLRs), which activate a series of intracellular signaling pathways. ${ }^{31}$ TLR (ligand-activated membrane-bound receptors) cause inflammatory responses utilizing $\mathrm{NF} \kappa \mathrm{B}$ activation. ${ }^{32}$ The NFkB enters into the nucleus and activates target gene transcription, resulting in products that cause inflammation. ${ }^{30}$

One such inflammation product is the macromolecular innate immune cell sensor, which produces an inflammatory response by caspase- 1 activating and secreting proinflammatory cytokines like interleukin $1 \beta .^{33,34}$

\section{Recruitment of White Blood Cells During Inflammation}

Blood leucocytes that include neutrophils, basophils, eosinophils, monocyte, macrophage, dendritic cells, and lymphocytes ( $\mathrm{B}$ and $\mathrm{T}$ cells) are an essential part of both innate and adaptive immune system which have immunestimulating or immune-suppressive functions. Alteration in blood WBC picture, occurring due to immune system activities, act as systemic inflammatory markers. ${ }^{35}$ The release of cytokines, lipid mediators, and vasoactive amines cause leucocyte recruitment during inflammation.
If it remains unchecked, the recruited cells cause tissue damage by releasing reactive oxygen and nitrogen. ${ }^{36}$

\section{Systemic Inflammatory Changes Due to Cement Dust}

Cement dust containing toxic substances like aluminum, silica, and chromium at work can trigger inflammatory changes in organs like the liver, skin, and lungs. Lipid peroxidation upon chronic aluminum exposure can lead to kidney failure, toxic changes in the nervous system. ${ }^{37}$ Aluminum also inhibits alkaline phosphatase, phosphodiesterase, hexokinase enzymes. ${ }^{38}$ Inhalation of chromium in hexavalent form may result in asthma, nasal blocking, nasopharyngeal pruritus; dermal contact causes skin burns, while ingestion can cause hepatic, renal, gastrointestinal damage. ${ }^{39}$ The systemic effects of cement dust and its toxic constituents have been researched in various studies. $^{12,40-45}$

A combined cross-sectional and cross-shift study was conducted among cement dust exposed 40 workers in Ethiopia in 2010 regarding acute lung function. The result analyzed with the unpaired and paired $t$-test, ANOVA, and Bonferroni test found respiratory symptoms in greater prevalence in workers with cement dust exposure in high amounts. There was $85 \%$ nose stuffiness, $47 \%$ having breath shortness, $45 \%$ with sneezing. The peak expiratory flow was reduced and most marked in subjects with high cement dust exposure. The association between peak expiratory flow, cross shift, and dust exposure level was significantly negative. Association was also found between peak expiratory flow for cross shift and several work years in high dust exposed segments. The research concluded a relationship between acute respiratory symptoms and exposure to dust produced in cement plants. ${ }^{40}$

Another cross-sectional study conducted in Ethiopia in 2015 researched the prevalence of chronic respiratory system symptoms and factors associated with 404 cement plant workers' symptoms. Variables associated with chronic symptoms of the respiratory system were found with multivariable regression and adjusted odds ratio. A high prevalence of chronic respiratory system symptoms (62.9\%) was noted among cement dust exposed workers, with $24.5 \%$ having chronic phlegm, 36.9\% chronic wheeze, $24.5 \%$ chronic cough, $21.0 \%$ chest pain, and $38.6 \%$ with chronic shortness of breath. The Association of chronic respiratory system symptoms was found with age, clinker, burner, cement plant, work experience, work 
safety, health training, smoking, chronic respiratory symptoms, gender with an adjusted odds ratio of 4.20, 2.28, $3.72,5.44,2.73,5.38,7.79$ and 2.07 , respectively. Thus, the researchers concluded that the respiratory system's chronic symptoms were in high prevalence with association factors of age, department of work, level of education, experience at work, training, gender, and smoking in cement plant workers. ${ }^{41}$

One more south Asian study was conducted among 50 nonsmoking cement manufacturing workers, another 50 subjects were unexposed to cement dust. The research work aimed to study the outcome of cement dust exposure for an extended period on lung functions. The workers were divided into three groups by exposure ( 5 or less, 5 to $10,>10$ years). They reported a significant decrease in Forced vital capacity, Peak Expiratory flow, Maximal Voluntary Ventilation, Forced Expiratory Volume in one second in cementproducing workers working for over ten years, compared to the control group. It was concluded that cement plant workers had significantly reduced lung function and impairment was more pronounced in subjects exposed to the dust for a more extended period. ${ }^{42}$

Research work was performed in Sokoto, Nigeria, with 56 cement mill workers having a mean of $10.2 \pm 5.6$ years of cement dust exposure and 96 subjects unexposed to the dust in 2007. The lung function parameters were observed and analyzed. It was noted that Forced Expiratory volume in one second and Vital capacity were reduced significantly in cement dust exposed workers compared to the control ( $p<0.005$ and $p<0.001$, respectively). They concluded that chronic exposure to this dust caused lung function impairment. ${ }^{43}$

A study done in Yemen in 2013 to observe the alteration of respiratory epithelium due to occupational exposure to cement dust reported a change in the cytology of the exposed group that was significant statistically $(p<0.05)$. Sputum samples of the participants (433 cement dust exposed and 98 control subjects) were studied and statistically analyzed. Among the cases, dysplasia was found in $21(4.8 \%)$, acute inflammatory infiltrated cells in $252(58.2 \%)$, squamous metaplasia in $236(54.5 \%)$, chronic inflammatory infiltrated cells in 45 (10.4\%), 54 (13\%) with Manila and Antinomies Israeli and viral infection in $39(9 \%)$ exposed subjects. Such findings led the researchers to suggest cement dust to be a risk factor for dysplasia, inflammation, squamous metaplasia, and infection susceptibility. ${ }^{44}$

Another study was conducted in Kimpese city of the Democratic Republic of the Congo, among 223 exposed and 156 less exposed workers from 2 cement mills in 2016. The study aimed to investigate the association of COPD and respiratory system prevalence symptoms working in cement dust. Multivariate analysis was done to observe this association. It was found that cough on most days and cough in the morning for as long as three months per year was higher in significance ( $\mathrm{p}=0.001$ and $\mathrm{p}<0.05$, respectively) in the group exposed to the dust than $\mathrm{o}$ the group less exposed. COPD prevalence in exposed was significantly higher $(p<0.001)$ than in control. The association of workers related to cleaning, production, and transportation department of cement factory with COPD were significant with Adjusted Odds Ratio of 14.49,3.09 and 3.37, respectively. This research suggested that workers of the cleaning, production, and transportation department of the cement industry were at greater risk of developing COPD and symptoms of respiratory system. ${ }^{45}$

A retrospective cohort study was performed in a cement plant of north Karnataka between 2010 and 2011. The research included 100 workers working at the plant for five years to study workers' morbidity at the cement plant. Upon researching and analyzing their medical records, it was observed that upper respiratory tract symptoms like allergic rhinitis, runny and stuffy nose were present in $45.3 \%$ of participants. Relative risk (RR) for the upper respiratory tract, dermatological, and lower respiratory tract symptoms were 2.6,2.18, and 2.3, respectively. Gastrointestinal tract complaints like diarrhea, hemorrhoids, and constipation were found in $21.8 \%$ exposed participants compared to $3.1 \%$ of the control group with RR of $1.06 .37 .5 \%$ of the cement dust workers $4.6 \%$ of controls who suffered from problems of oral cavity like plaque, caries, pathos ulcer. Musculoskeletal problems were also noted in $18.8 \%$ of workers with dust exposure, while $4.6 \%$ of control suffered from such problems with $1.7 \mathrm{RR}$. This study concluded that health problems were more in cement dust-exposed workers than those not exposed to this toxic dust. ${ }^{12}$ 


\section{White Blood Cell Count as Inflammatory Markers}

In clinical practice, markers are used to check biological processes and evaluate therapeutic responses. The inflammatory response features predict inflammatory disease and observe inflammatory disease cause and outcome relationship. ${ }^{29,46}$ Analysis of these markers can be a nonspecific means of determining underlying diseases. ${ }^{47}$

WBCs' absolute and differential counts is considered hematological markers of the systemic response to inflammation. Testing these markers is affordable and measuring these routinely is possible. ${ }^{35}$ Similar considerable research in Africa, Asia, and the Middle East has observed that cement dust exposure results in hematological alterations, including $\mathrm{WBC} .^{11,37,48} \mathrm{~A}$ raised $\mathrm{WBC}$ may result from inflammation upon exposure to cement dust. Leukocytosis in the peripheral blood is a cellular marker of inflammation and ongoing tissue inflammation. Thus, it might be seen as a biomarker of inflammatory response. ${ }^{49}$

Researchers in various countries have noted alterations in the total WBC count and its differentials in cement factory workers. ${ }^{37,48,50,51}$ However, in Bangladesh, data on this topic is not sufficient. This study investigates the influence of occupational cement dust exposure on both total and differential counts of WBCs as inflammatory markers in cement manufacturing plant workers.

\section{Materials and Methods Study Design}

This was a cross-sectional study; 92 healthy male participants were enrolled. Of the 92 recruits, 46 (study group), were occupationally exposed to cement dust for 2 years and more, aged 20-50 years. The study subjects were from a cement manufacturing plant in Munshiganj, Bangladesh. The other 46 subjects (control group) hailed from Dhaka City (The Capital of the Country) of Bangladesh with no cement dust exposure history. The control group was matched with the study group regarding weight, height, age, social and economic conditions.

\section{Sample Size Calculation}

The sample size was estimated based on the difference between the two means from the previous study. ${ }^{51} \mathrm{We}$ assumed the level of significance was $5 \%$. The sample size obtained for this study was 46 subjects for each group. [Group A = Study Population, Group B = Control Group, of 46 subjects for each group]

\section{Study Population}

The study subjects (Group A) age 20-50 years, who have been occupationally exposed to cement dust for two years and longer were selected from a cement manufacturing plant in Munshiganj, near Dhaka city, Bangladesh. Seemingly, healthy control subjects (Group B) were recruited by personal contact from different parts of Dhaka city after matching height, weight, age, social and economic conditions with the study group. Excluded from this study were those with a history of diseases of the respiratory system, cardiovascular system, hematological system, liver, kidney. Subjects with acute infection, malignancies, history of anticoagulant use, taking iron therapy, chemotherapy, and history of having blood transfusion within three months before the study were excluded. Those subjects having a known history of allergy were also excluded from the study.

\section{Sampling Method}

The non-randomized purposive sampling method was used to carry out this study.

\section{Study Period}

This study was performed in the year between 2017 and 2018.

\section{Study Place}

Physiology Department of Dhaka Medical College located in Dhaka city, Bangladesh

\section{Preparation of Questionnaire}

This study's questionnaire was prepared and adapted from Occupational Safety and Health Administration (OSHA) standard questionnaire ${ }^{52,53}$ and modified Kuppuswamy socioeconomic scale. ${ }^{54}$ The questionnaire was modified, considering the criteria of Inclusion, exclusion, and Bangladeshi cultural background. There were three segments in the questionnaire. The demographic data were collected in the first segment. Questions about personal history: a history of smoking, alcohol intake, drug history, family history, medical history, and duration of cement dust exposure (applicable for cement dust-exposed subjects) were included in the second segment. "Yes," "No," and "others" were noted as answers for this part of the questionnaire. The values obtained from the participants' physical examination were recorded in the last segment of the questionnaire. 


\section{Data Collection}

The questionnaires were prepared in the native language of the participants and English and collected through face-toface interviews. After explaining the study objectives to the participants, written informed consent was collected from them. Then the information needed for completing the questionnaire was taken from them. The study group from the cement manufacturing plant included participants in the sections with most cement dust in their surroundings, such as bagging, loading, milling, and crushing. ${ }^{51}$ Coding was done to keep the respondents' personal information anonymous.

\section{Sample Collection}

The ante-cubital vein was located, and $3 \mathrm{~mL}$ of blood was drawn from the blood and then transferred to an EDTA anticoagulant containing test tube to determe total WBC count and its' differentials. These parameters were determined with an automated haematoanalyser. The blood sample was analyzed by the Department of Laboratory Medicine, Dhaka Medical College Hospital, Dhaka, Bangladesh.

\section{Data Analysis}

The completed questionnaire data were compiled, appropriately sorted, and analyzed using Statistical Package for Social Sciences [(SPSS) IBM Corp. Released 2019. IBM SPSS Statistics for Windows, Version 26.0. Armonk, NY; IBM Corp]. Results were expressed as Frequency, Percentage, Mean with standard deviation, Box Plot, Scatter Diagram, and Bar Diagram. Independent samples $t$-test was performed to compare the Quantitative data. The chi-square test was used to compare the Qualitative data. Pearson's correlation (r) test was conducted to ascertain the correlation between total WBC count and cement dust exposure duration. Univariate Regression analysis producing Odds Ratio was done to commemorate the association of the total WBC count between cement dust-exposed recruits and those not exposed to the cement dust. Multivariate Regression analysis producing Odds Ratio was performed to assess the association between the total count of WBC with the duration of cement dust exposure. For the Multivariate Regression analysis, the Dependent Variable was the total WBC count, Independent Variable was the duration of cement dust exposure, and the covariant was Age of the cement dust-exposed recruits. The accepted significance level for the $p$ value was less than 0.05 .

\section{Project and Earlier Manuscript Details}

The current research was part of a project containing two parts.

1. Chronic exposure to cement dust impacts Red Blood cells (RBC) and hemoglobin ( $\mathrm{Hb})$. The study was conducted among cement factory workers in Bangladesh. This section of the project was already published as "Effects of exposure to cement dust on hemoglobin concentration and total count of RBC in cement factory workers." http://www. banglajol.info/index.php/JBSP/article/view/ $39480 .{ }^{55}$ This part of the study revealed that the total count of RBC was lower among the cementexposed group than those of the statistically significant control group $(p<0.05)$. Furthermore, $\mathrm{Hb}$ concentration has negatively correlated with the duration of cement dust exposure which was also statistically significant $(p<0.001)$.

2. Chronic exposure to cement dust impacts WBC and inflammatory response. The current discusses the second part of the project.

\section{Difference Between the Two Manuscripts}

The first part of the project concentrated on whether anemia was aggravated by occupational exposure to cement dust. The focus of that part of the project was on anemia in cement dust workers because anemia is rampant in a country like Bangladesh. ${ }^{56}$

This second part of the project regarding the effects of occupational cement dust exposure focuses specifically on changes in the inflammatory markers: Total and differential count of WBCs upon exposure to cement dust. Inflammatory changes brought about by the toxic effects of cement dust may result in the deterioration of human health due to organ damage. Therefore, observing changes in these inflammatory markers can be an inexpensive way of early detection and protection of the lives of many underprivileged workers.

The difference between the first part of the project and this present article is that the first part focused only on RBC count and Hemoglobin concentration in cement dust exposed subjects and observed whether this toxic dust aggravates anemia. This article solely focuses on observing whether cement dust triggers inflammation in those exposed to cement dust occupationally. Furthermore, there are differences between the two articles in the methods of 
data analysis and presentation. In the previous article on the effects of cement dust exposure on Hemoglobin concentration and total RBC count, Independent samples $t$-test and Pearson's correlation ( $r$ ) test were performed; data were presented as Mean, standard deviation, and scatter diagram. Whereas in the current paper of the project, a more detailed data analysis and presentation has been done, which includes Independent samples $t$-test, chisquare test, Pearson's correlation (r) test, Univariate Regression analysis producing Odds Ratio and Multivariate Regression analysis producing Odds Ratio and data has been presented as Frequency, Percentage, Mean with standard deviation, Box Plot, Scatter Diagram, and Bar Diagram. Also, more detailed information has been presented for the socioeconomic, personal, medical, and family history in this article which was not included in the previous article.

Each part of the project focuses on a different aspect, mechanism of effect, and outcome of cement dust exposure on human health.

\section{Details Ethics Statement}

All procedures performed in this study involving human participants were in accordance with the ethical standards of the institutional and/or national research committee and with the 1964 Helsinki declaration and its later amendments or comparable ethical standards. Thereby, this study was approved by the Research Review Committee and Ethical Review Committee of Dhaka Medical College Dhaka-1000, Bangladesh [Reference No.: MEU-DMC/ECC/2018/06, dated 02.01.2018]. All the recruits for this study gave written informed consent and the history of all subjects noted in the questionnaire before collecting blood samples from them. All recruits' socio-economic condition was determined from their educational, occupational, and monthly family income history. The socioeconomic status was divided into high, middle, and low socioeconomic conditions according to the modified Kuppuswamy socioeconomic scale. ${ }^{54}$ Blood pressure along with the anthropometrical values was measured. Recording of the collected information was done in the questionnaire. Protection of the privacy of the participants was ensured as all the information provided by them remains undisclosed.

\section{Results}

\section{Socio-Demographic Characteristics of the Recruits}

There were 92 male recruits, 46 were cement dust exposed recruits, and 46 were control subjects. The mean age for cement dust revealed recruits and the control was $33.17 \pm$ 8.27 years and $33.52 \pm 7.87$ years. The mean BMI of the recruits with cement dust exposure and control was 23.14 \pm $2.06 \mathrm{~kg} / \mathrm{m}^{2}$ and $23.71 \pm 2.61 \mathrm{~kg} / \mathrm{m}^{2}$. The Blood Pressure means was found to be $117.72 \pm 15.06 \mathrm{~mm} \mathrm{Hg}$ (Systolic); $71.74 \pm 9.51 \mathrm{~mm} \mathrm{Hg}$ (Diastolic), and 113.04 $\pm 12.09 \mathrm{~mm}$ $\mathrm{Hg}$ (Systolic); 70.87 $\pm 9.11 \mathrm{~mm} \mathrm{Hg}$ (Diastolic) in cement dust-exposed recruits and control group, respectively. Age, systolic, diastolic blood pressure, height, weight, and Basal Metabolic Index showed no difference statistically (Table 1, Figures 2-7). Out of the recruits in both groups, the majority were followers of Islam, $42(91.3 \%)$ in cement dust-exposed recruits and $46(100 \%)$ in the control recruits. About $25(54.3 \%)$ and $27(58.7 \%)$ of the cement dust-exposed recruits and control group, respectively, had attended primary school. Another 11 (23.9\%) and 9 (19.6\%) of the cement dust-exposed recruits and control group, respectively, had obtained the Secondary School Certificate. The rest of the recruits in both groups had no formal education. In the marital status, the Majority of the study recruits were married; $35(76.1 \%)$ in each group were married. $27(58.7 \%)$ of the cement dust-exposed recruits and $26(56.5 \%)$ of the control group received a monthly income in Bangladeshi currency (Taka) between

Table I Physical Characteristics of the Study Recruits in Both Groups

\begin{tabular}{|l|l|l|l|}
\hline & $\begin{array}{l}\text { Cement } \\
\text { Dust } \\
\text { Exposed } \\
\text { Recruits }\end{array}$ & $\begin{array}{l}\text { Cement Dust } \\
\text { Unexposed } \\
\text { Recruits (Control) }\end{array}$ & $p$ value \\
\hline BMI $\left(\mathrm{kg} / \mathrm{m}^{2}\right)$ & $23.14 \pm 2.06$ & $23.71 \pm 2.61$ & NS \\
\hline Age (years) & $33.17 \pm 8.27$ & $33.52 \pm 7.87$ & NS \\
\hline $\begin{array}{l}\text { Diastolic BP } \\
(\mathrm{mmHg})\end{array}$ & $71.74 \pm 9.51$ & $70.87 \pm 9.11$ & NS \\
\hline $\begin{array}{l}\text { Systolic BP } \\
(\mathrm{mmHg})\end{array}$ & $\begin{array}{l}117.72 \pm \\
15.06\end{array}$ & $113.04 \pm 12.09$ & NS \\
\hline
\end{tabular}

Notes: Statistical analysis was performed by Independent sample $t$-test, data expressed in Mean \pm SE.

Abbreviations: NS, not significant; BP, blood pressure; BMI, body mass index. 


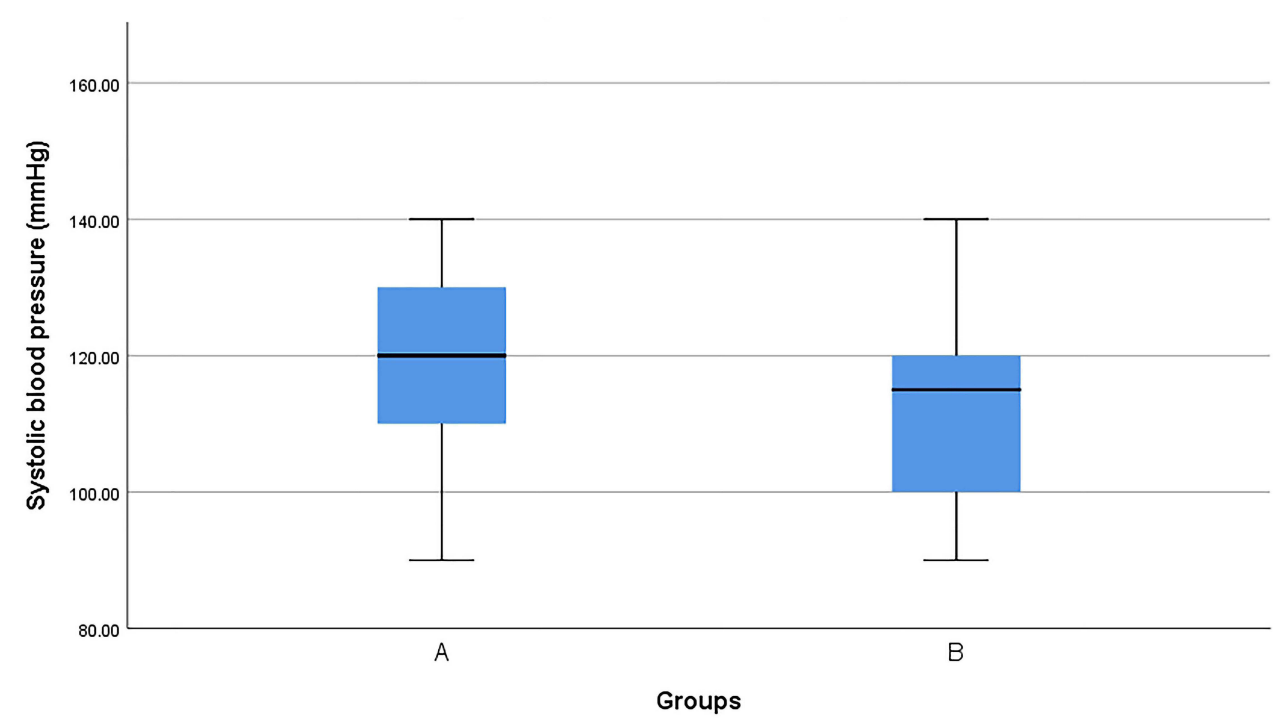

Figure 2 Box plot of systolic blood pressure in both groups ( $N=92)$. Group A: cement dust-exposed recruits. Group B: healthy cement dust unexposed recruits (control).

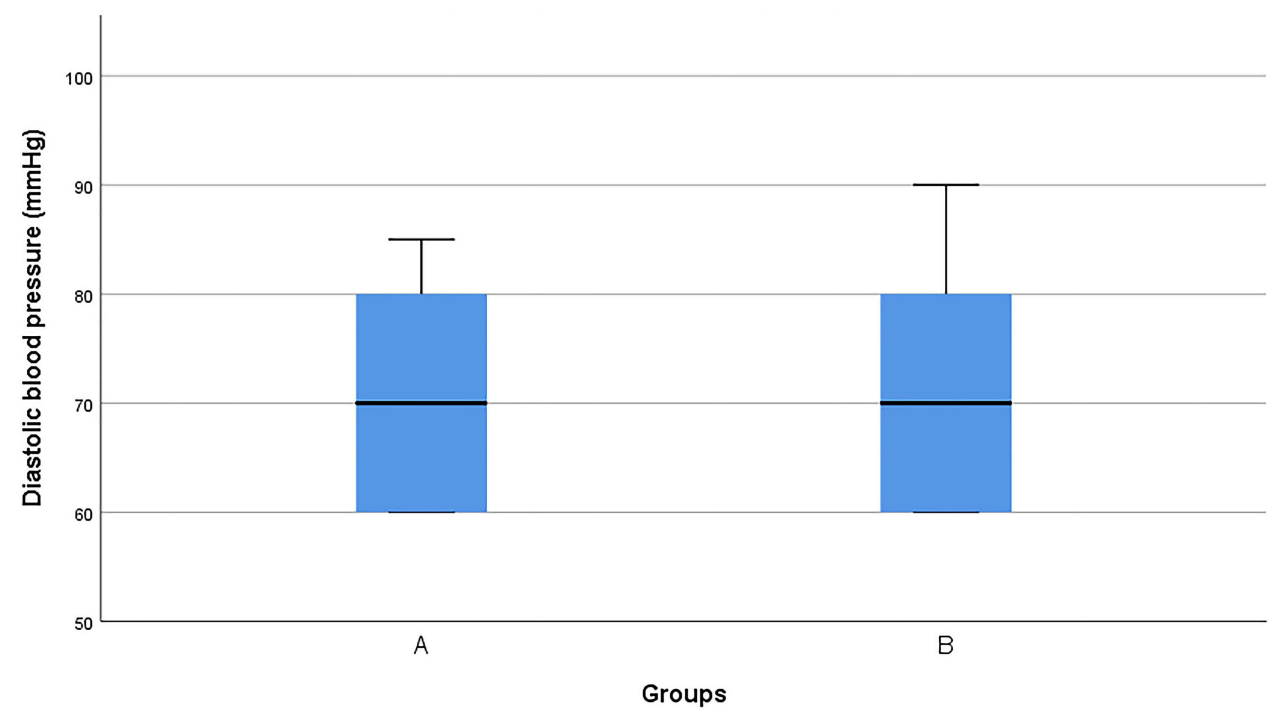

Figure 3 Box plot of diastolic blood pressure in both groups ( $\mathrm{N}=92)$. Group A: cement dust-exposed recruits. Group B: healthy cement dust unexposed recruits (control).

Taka 10,000-15,000 (Table 2). No significant differences were observed for the socio-demographic characteristics between the groups.

\section{Personal History, Family History, and Medical History of the Study Recruits}

Of the 92 study recruits, $37(80.4 \%)$ of the cement dustexposed recruits and $38(82.6 \%)$ of the control group were nonsmokers. None of the study recruits were alcohol consumers. In the case of drug history of the study recruits, 1 $(2.2 \%)$ of the cement dust-exposed recruits, and $3(6.5 \%)$ from the control group had a history of taking vitamin supplementation (Table 3).

Family History of Hypertension, Diabetes Mellitus was observed in the case of $4(8.7 \%)$ and $3(6.5 \%)$, respectively, for cement dust-exposed recruits. In comparison, in the control group, $6(13 \%), 5(10.9 \%)$, and $1(2.2 \%)$ reported a family history of hypertension, diabetes mellitus, and bronchial asthma, respectively (Table 4).

Out of the cement, dust-exposed recruits, 2 (4.3\%) and $4(8.7 \%)$ of the control group reported having a medical history of Diabetes Mellitus. 1 (2.2\%) of the recruits in the 


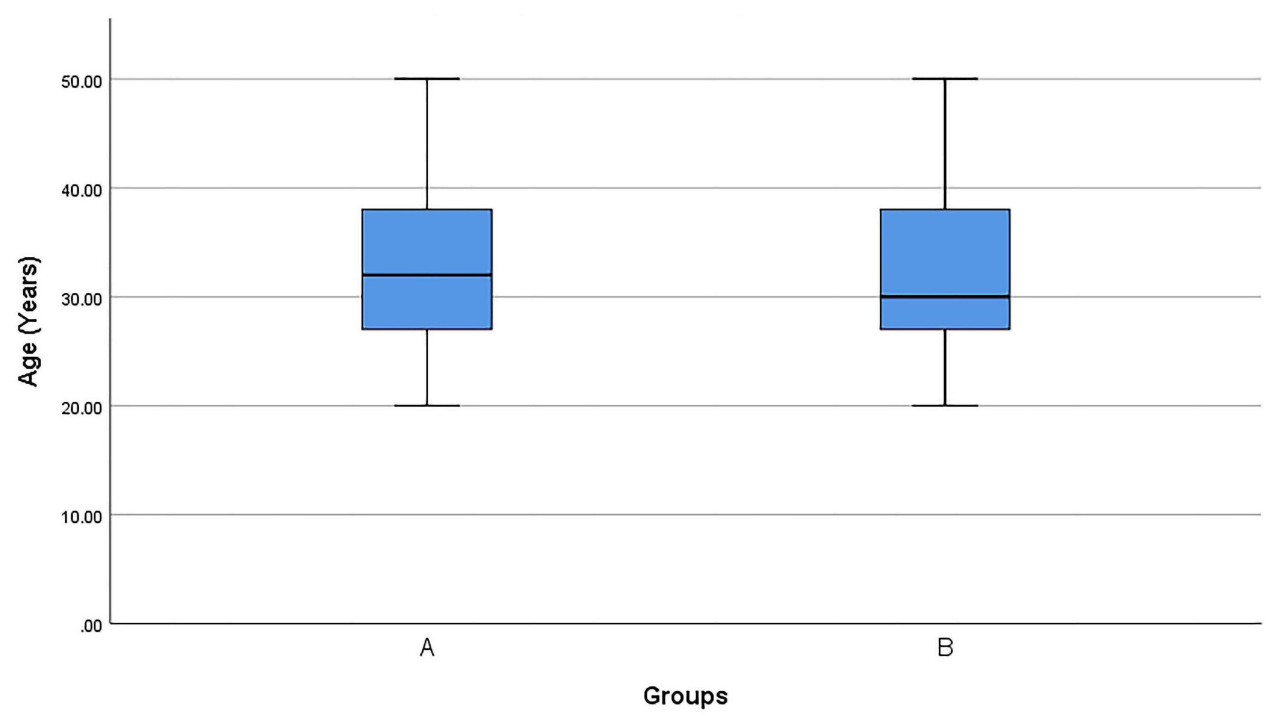

Figure 4 Box plot of age in both groups ( $N=92)$. Group A: cement dust-exposed recruits. Group B: healthy cement dust unexposed recruits (control).

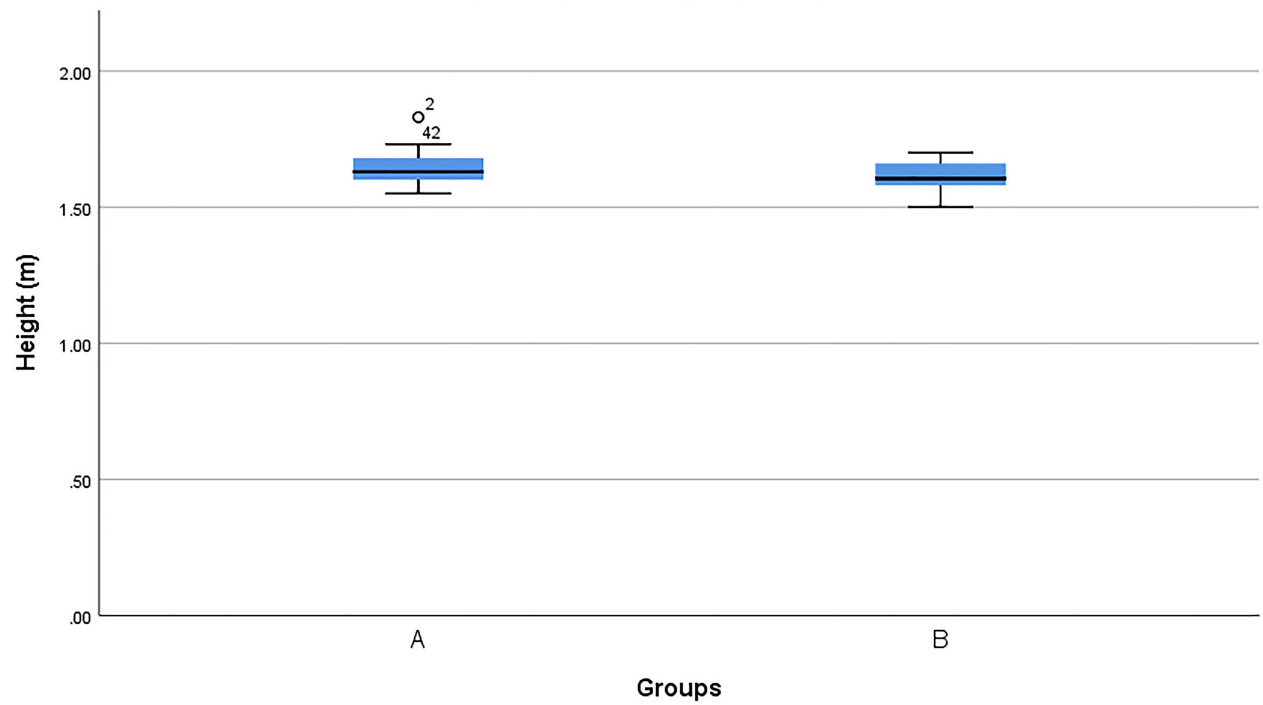

Figure 5 Box Plot of Height in both groups ( $N=92)$. Group A: cement dust-exposed recruits. Group B: healthy cement dust unexposed recruits (control). ${ }^{\circ}$ Participant number 2 , and 42 were outliers of Group $A$.

control group had a history of undergoing surgery about one year before being recruited in the study (Table 5). No significant differences were observed in the groups' personal history, family history, and medical history.

\section{Total WBC Count with Its Differentials in the Study Recruits}

In this study, the total WBC count displayed a statistically higher significant value in recruits occupationally exposed to cement dust when compared to the control group (Table 6, Figures 8 and 9). Recruits not exposed to cement dust were less likely to have Total $\mathrm{WBC}$ count alteration $(\mathrm{OR}=0.122$,
$95 \% \mathrm{CI}=0.047$ to 0.311 ) than the recruits exposed to cement dust (Table 6). In the differential count of WBC, Lymphocyte and Eosinophil count was significantly higher in subjects exposed to cement dust than the control group (Table 7, Figure 10). WBC count was found $<8 \times 10^{3} / \mu \mathrm{L}$ in 16 (34.8\%) cases, $16(34.8 \%)$ cases had cement dust exposure for $\leq 5$ years, and $30(65.2 \%)$ cases had $>5$ years (Table 8 ). The change in $\mathrm{WBC}$ count showed a positive correlation with cement dust exposure duration (Figure 11). This study analysis also shows a significant association (Table 9) between Total WBC count and cement dust exposure duration $[\mathrm{OR}=4.42 ; 95 \% \mathrm{CI}(1.56,12.47) ; p 0.005]$. 


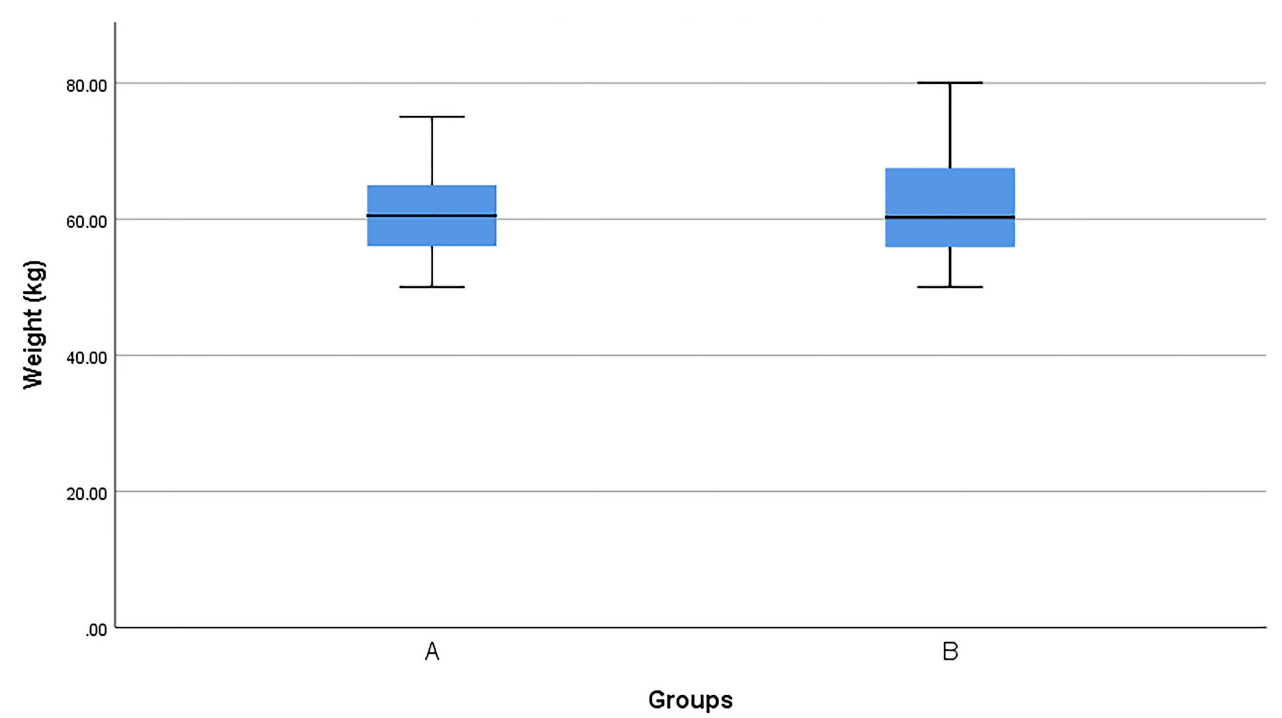

Figure 6 Box plot of weight in both groups (N=92). Group A: cement dust-exposed recruits. Group B: healthy cement dust unexposed recruits (control).

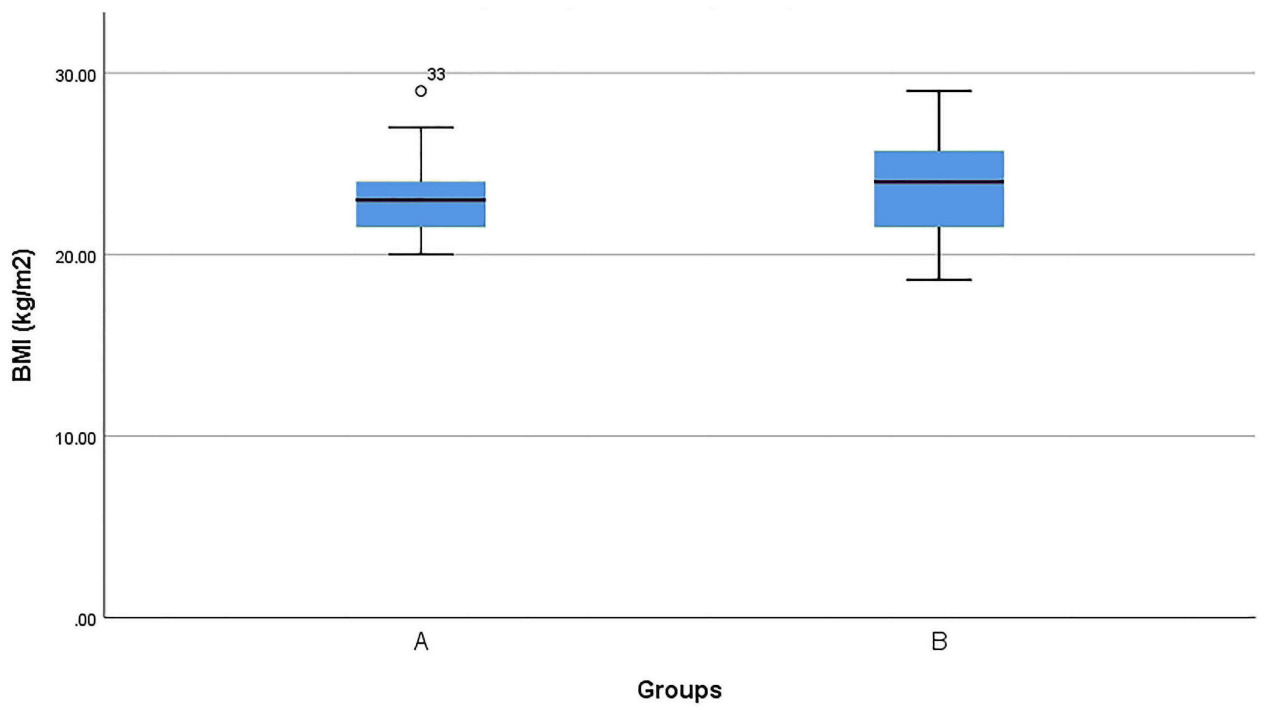

Figure 7 Box plot of BMI in both groups ( $N=92)$. Group A: cement dust-exposed recruits. Group B: healthy cement dust unexposed recruits (control). ${ }^{\circ}$ Participant number 33 is an outliers of Group A.

\section{Discussion}

The total WBC count, differential count of Lymphocyte and Eosinophil were found in the present study to be higher in recruits exposed to cement dust than controls. This study revealed a. positive correlation found between the total WBC count and the duration of exposure to cement dust.

In the present study, significantly higher mean WBC, lymphocyte, and eosinophil counts $(p<0.05)$ were noted in cement dust-exposed subjects than that of nonexposed individuals. Similar findings were observed by previous studies carried out in various parts of the world..$^{37,51,57}$ However, no significant alterations in WBC with its differentials in subjects exposed to cement dust compared to controls were found by Salh et al in 2014. This disagreement between the findings of Salah et al (2014) and the present study might have occurred due to differences in the cement dust exposure duration. The cement dust exposure duration in the research work of Salah et al (2014) was on average four years, whereas the exposure duration in the present study was $7.17 \pm 2.78$ years. ${ }^{58}$ 
Table 2 Socioeconomic Characteristics of the Recruits in Both Groups

\begin{tabular}{|c|c|c|c|}
\hline Variable & $\begin{array}{l}\text { Cement } \\
\text { Dust } \\
\text { Exposed } \\
\text { Recruits }\end{array}$ & $\begin{array}{l}\text { Cement Dust } \\
\text { Unexposed } \\
\text { Recruits } \\
\text { (Control) }\end{array}$ & $p$ value \\
\hline $\begin{array}{l}\text { Monthly income } \\
5000-10,000 \\
10,000-15,000\end{array}$ & $\begin{array}{l}19(41.3 \%) \\
27(58.7 \%)\end{array}$ & $\begin{array}{l}20(43.5 \%) \\
26(56.5 \%)\end{array}$ & 0.833 \\
\hline $\begin{array}{l}\text { Educational status } \\
\text { No formal education } \\
\text { Primary } \\
\text { SSC }\end{array}$ & $\begin{array}{l}10(21.7 \%) \\
25(54.3 \%) \\
11(23.9 \%)\end{array}$ & $\begin{array}{c}10(21.7 \%) \\
27(58.7 \%) \\
9(19.6 \%)\end{array}$ & $0.87 I$ \\
\hline $\begin{array}{l}\text { Religion } \\
\text { Islam } \\
\text { Hindu } \\
\text { Christian }\end{array}$ & $\begin{array}{c}42 \text { (9l.3\%) } \\
3(6.5 \%) \\
\text { I }(2.2 \%)\end{array}$ & $\begin{array}{c}46(100 \%) \\
0(0 \%) \\
0(0 \%)\end{array}$ & 0.124 \\
\hline $\begin{array}{l}\text { Marital status } \\
\text { Married } \\
\text { Un married }\end{array}$ & $\begin{array}{l}35(76.1 \%) \\
\text { II (23.9\%) }\end{array}$ & $\begin{array}{l}35(76.1 \%) \\
\text { II }(23.9 \%)\end{array}$ & 1.000 \\
\hline
\end{tabular}

Notes: Data were expressed in frequency and percentage of socioeconomic characteristics of the study recruits; total number of recruits: 92; the number of recruits in each group: 46.

Table 4 Family History of Study Recruits in Both Groups

\begin{tabular}{|l|l|l|l|}
\hline Variable & $\begin{array}{l}\text { Cement Dust } \\
\text { Exposed } \\
\text { Recruits }\end{array}$ & $\begin{array}{l}\text { Cement Dust } \\
\text { Unexposed Recruits } \\
\text { (Control) }\end{array}$ & p value \\
\hline \multicolumn{4}{|l|}{ Family History of Hypertension } \\
\hline $\begin{array}{l}\text { Yes } \\
\text { No }\end{array}$ & $\begin{array}{l}4(8.7 \%) \\
42(91.3 \%)\end{array}$ & $\begin{array}{l}6(13 \%) \\
40(87 \%)\end{array}$ & 0.503 \\
\hline Diabetes Mellitus & $\begin{array}{l}5(10.9 \%) \\
4 I(89.1 \%)\end{array}$ & 0.459 \\
\hline $\begin{array}{l}\text { Yes } \\
\text { No }\end{array}$ & $\begin{array}{l}43(9.5 \%) \\
\text { Bronchial Asthma }\end{array}$ & 0.313 \\
\hline $\begin{array}{l}\text { Yes } \\
\text { No } \\
\text { COPD } \\
\text { Hemolytic } \\
\text { Anemia } \\
\text { Thalassemia } \\
\text { Malignancy }\end{array}$ & $\begin{array}{l}0(0 \%) \\
0(0 \%)\end{array}$ & $\begin{array}{l}1(2.2 \%) \\
0(0 \%)\end{array}$ & $\begin{array}{l}0(0 \%) \\
0(0 \%)\end{array}$ \\
\hline
\end{tabular}

Notes: Data were expressed as frequency and percentage; total number of recruits: 92; number of recruits in each group: 46.

Emmanuel et al (2015) found a significant increase in total WBC count with an increased cement dust exposure period, similar to the present study's observation. The
Table 3 Personal History of Study Recruits in Both Groups

\begin{tabular}{|c|c|c|c|}
\hline Variable & $\begin{array}{l}\text { Cement } \\
\text { Dust } \\
\text { Exposed } \\
\text { Recruits }\end{array}$ & $\begin{array}{l}\text { Cement } \\
\text { Dust } \\
\text { Unexposed } \\
\text { Recruits } \\
\text { (Control) }\end{array}$ & $p$ value \\
\hline $\begin{array}{l}\text { Smoking habit } \\
\text { Yes } \\
\text { No } \\
\text { Alcohol Intake }\end{array}$ & $\begin{array}{l}9(19.6 \%) \\
37(80.4 \%) \\
0(0 \%)\end{array}$ & $\begin{array}{l}8(17.4 \%) \\
38(82.6 \%) \\
0(0 \%)\end{array}$ & $\begin{array}{l}0.788 \\
-\end{array}$ \\
\hline $\begin{array}{l}\text { Drug History } \\
\text { Anti-Hypertensive } \\
\text { Anti -Diabetic } \\
\text { Broncho-dialator } \\
\text { Steroid }\end{array}$ & $\begin{array}{l}0(0 \%) \\
0(0 \%) \\
0(0 \%) \\
0(0 \%)\end{array}$ & $\begin{array}{l}0(0 \%) \\
0(0 \%) \\
0(0 \%) \\
0(0 \%)\end{array}$ & $\begin{array}{l}- \\
- \\
- \\
-\end{array}$ \\
\hline $\begin{array}{l}\text { Vitamin Supplementation } \\
\text { Yes } \\
\text { No } \\
\text { Anti -Allergic drug } \\
\text { Iron Therapy } \\
\text { Chemotherapy } \\
\text { Anticoagulant }\end{array}$ & $\begin{array}{l}\mathrm{I}(2.2 \%) \\
45(97.8 \%) \\
0(0 \%) \\
0(0 \%) \\
0(0 \%) \\
0(0 \%)\end{array}$ & $\begin{array}{l}3(6.5 \%) \\
43(93.5 \%) \\
0(0 \%) \\
0(0 \%) \\
0(0 \%) \\
0(0 \%)\end{array}$ & $\begin{array}{l}- \\
- \\
-\end{array}$ \\
\hline
\end{tabular}

Notes: Data were expressed as frequency and percentage; total number of recruits: 92; number of recruits in each group: 46 .

total WBC count value was higher in significance for occupationally cement dust exposed recruits for more than five years. ${ }^{51}$ On the contrary, Okonkwo et al found the total WBC count decreased with exposure to cement dust. ${ }^{59}$ Such disparity may be due to variation in race and differences in the number of subjects taken.

The positive correlation of the total count of WBC with the duration of exposure to cement dust observed in this study agrees with Mojiminiyi et al (2007), who also found a positive correlation between WBC count and increase in the duration of exposure to cement dust. $^{60}$ However, Mandal and Suva (2014) found no significant changes in the hematological parameters with the period of exposure. ${ }^{61}$ The hematological parameters were determined manually by Mandal and Suva (2014), while an automated hematology analyzer was used in the present study. Mandal and Suva (2014) performed their analysis on cement dust exposure in construction workers, while this study was carried out on cement plant workers who are likely to be exposed to higher cement dust levels. This difference in hematological analysis and place of study may have caused the researchers' findings. 
Table 5 Medical History of Study Recruits in Both Groups

\begin{tabular}{|l|l|l|l|}
\hline Variable & $\begin{array}{l}\text { Cement } \\
\text { Dust } \\
\text { Exposed } \\
\text { Recruits }\end{array}$ & $\begin{array}{l}\text { Cement } \\
\text { Dust } \\
\text { Unexposed } \\
\text { Recruits }\end{array}$ & p value \\
\hline Medical History & & & \\
Cardiovascular disease & $0(0 \%)$ & $0(0 \%)$ & - \\
\hline Diabetes Mellitus & & & \\
Yes & $2(4.3 \%)$ & $4(8.7 \%)$ & 0.401 \\
No & $44(95.7 \%)$ & $42(91.3 \%)$ & \\
Bronchial Asthma & $0(0 \%)$ & $0(0 \%)$ & - \\
COPD & $0(0 \%)$ & $0(0 \%)$ & - \\
Allergy & $0(0 \%)$ & $0(0 \%)$ & - \\
Iron deficiency Anemia & $0(0 \%)$ & $0(0 \%)$ & - \\
Thalassemia & $0(0 \%)$ & $0(0 \%)$ & - \\
Liver disease & $0(0 \%)$ & $0(0 \%)$ & - \\
Renal Disease & $0(0 \%)$ & $0(0 \%)$ & - \\
Acute Infection & $0(0 \%)$ & $0(0 \%)$ & - \\
Malignancy & $0(0 \%)$ & $0(0 \%)$ & - \\
\hline Surgery & & & - \\
Yes & $0(0 \%)$ & $1(2.2 \%)$ & 0.313 \\
No & $46(100 \%)$ & $45(97.8 \%)$ & \\
History of receiving blood & $0(0 \%)$ & $0(0 \%)$ & - \\
transfusion & & & \\
\hline Notes: Dar were & & \\
\hline
\end{tabular}

Notes: Data were expressed as frequency and percentage; total number of recruits: 92; number of recruits in each group: 46.

\section{Inflammatory Response to Cement Dust}

The statistically significant increase in the total count of WBCs and differential count of lymphocytes observed in this study may be due to the Chronic inflammation taking place in the lungs upon repeated exposure to this dust containing heavy metals like Crystalline silica-alumina. ${ }^{62}$ The innate immune response begins upon crystalline silica exposure with proinflammatory cytokine, which causes infiltration of inflammatory cells like neutrophils, macrophages, and lymphocytes. ${ }^{63}$ When crystalline silica, alumina is engulfed by Alveolar Macrophage, reactive oxygen species are released from mitochondria, and phagolysosomal membrane lipid peroxidation occurs. ${ }^{64}$ Mitochondria-derived reactive oxygen species and cathepsin protease released from phagolysosomal membrane destabilization cause activation of NLRP3 inflammasomes. ${ }^{65}$ The NLRP3 (nucleotide-binding oligomerization domain receptor, pyrin domain-containing 3) inflammasomes are pattern recognition receptors that, when activated, cause cathepsin 1 to activate proinflammatory cytokines Interleukin $1 \beta$, Interleukin 18 that promote inflammation. ${ }^{66}$ During inflammation, specific transcription factors activation like NF $\kappa \mathrm{B}$ occurs. ${ }^{67}$ There is the activation of $N F \kappa \beta$, which leads to the formation of inflammatory mediators and cytokines like interleukins (IL$1 \beta$, IL-6, IL-8, IL-10) and tumor necrosis factor- $\alpha$ (TNF- $\alpha$ ). Such transcription factors stimulate the inflammatory response and tissue damage (Figure 12). ${ }^{67,68}$

During the adaptive immune response to Crystalline silica-containing dust, CD4+ T cells such as T-helper 1, T-helper 2, T-helper 17, and regulatory $\mathrm{T}$ (Treg) cells play an essential part in the development of pulmonary inflammation. ${ }^{69}$ T-helper 17 subsets of lymphocyte secrete Interleukin 17 that is proinflammatory in nature. ${ }^{70}$

The increase in eosinophil count was statistically significant in this study due to the inflammatory response triggered by particulate exposure, causing eosinophil accumulation. ${ }^{71}$ The immune response to dust particles in the lungs induces antigen-specific IgG1 and IgE release utilizing DAMPs and cytotoxic chemicals like aluminum oxide. $^{62,72,73}$ This, in turn, may result in an allergic response in the body. ${ }^{72}$

\section{Health Policies Adopted by Cement Industries Around the World}

Cement Sustainability Initiative, consisting of 24 cement manufacturers operating worldwide in over 100 countries, has agreed upon and implemented health

Table 6 Total WBC Count of the Cement Dust Exposed Recruits and Those Unexposed to Cement Dust

\begin{tabular}{|c|c|c|c|c|c|}
\hline Parameters & $\begin{array}{c}\text { Cement Dust Exposed } \\
\text { Recruits }\end{array}$ & $\begin{array}{c}\text { Cement Dust Unexposed } \\
\text { Recruits (Control) }\end{array}$ & $\begin{array}{l}\text { Mean Difference } \\
\qquad(95 \% \mathrm{Cl})\end{array}$ & $\begin{array}{l}\text { Odds Ratio (OR) } \\
\qquad(95 \% \mathrm{Cl})\end{array}$ & $p$ value \\
\hline $\begin{array}{l}\text { WBC count } \\
\left(\times 10^{3} / \mu \mathrm{L}\right)\end{array}$ & $9.57 \pm 3.02$ & $7.62 \pm 1.79$ & 1.95 (0.935 to 2.965$)$ & $\begin{array}{c}0.122(0.047 \text { to } \\
0.31 \mathrm{I})\end{array}$ & $\begin{array}{c}< \\
0.001^{* * * *}\end{array}$ \\
\hline
\end{tabular}

Notes: An Independent sample t-test was performed for statistical analysis to compare between the two groups; Mean \pm SE was used to express the data; Univariate Regression analysis showing Odds Ratio was performed to observe the association of total WBC count between Cement Dust Exposed recruits and control; Total number of recruits: 92; Number of recruits in each group: 46; ***Highly Significant.

Abbreviation: WBC, White blood cell. 


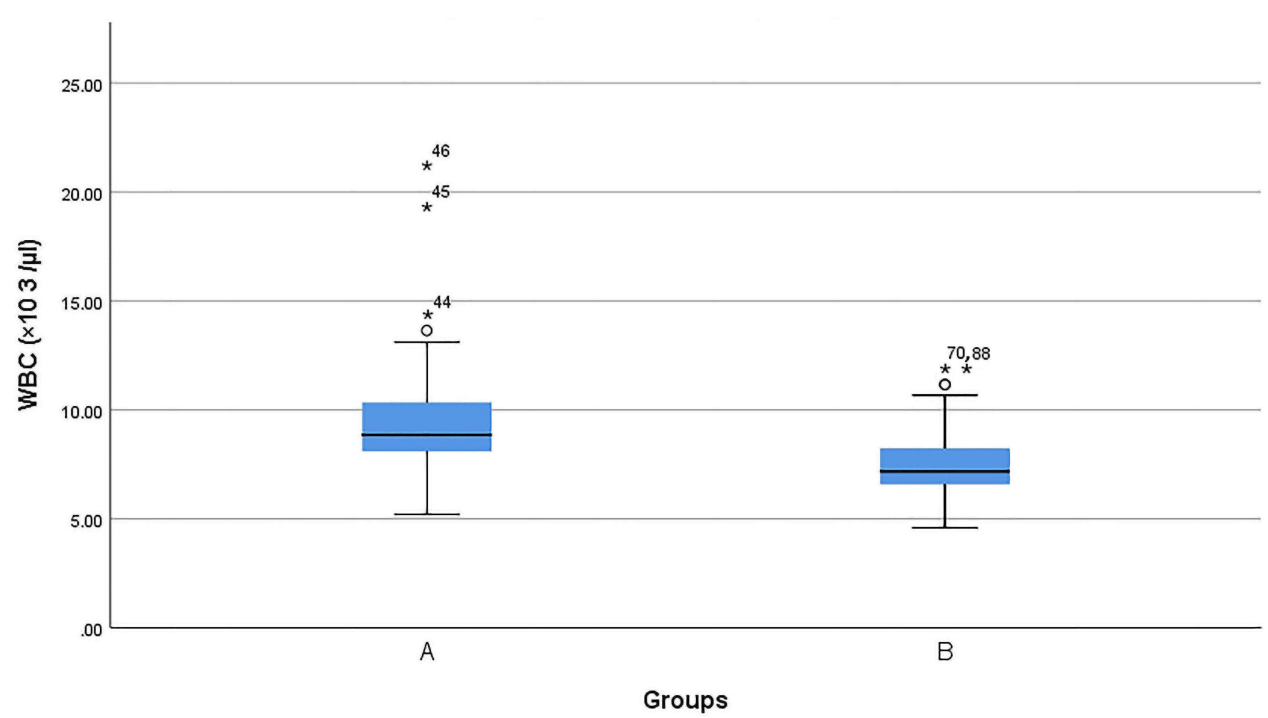

Figure 8 Box Plot of Total WBC count in both groups ( $N=92)$. Group A: cement dust-exposed recruits. Group B: healthy cement dust unexposed recruits(control). *Participant number 43, 44, 45 and 70, 88 were outliers of Group A, Group B respectively.

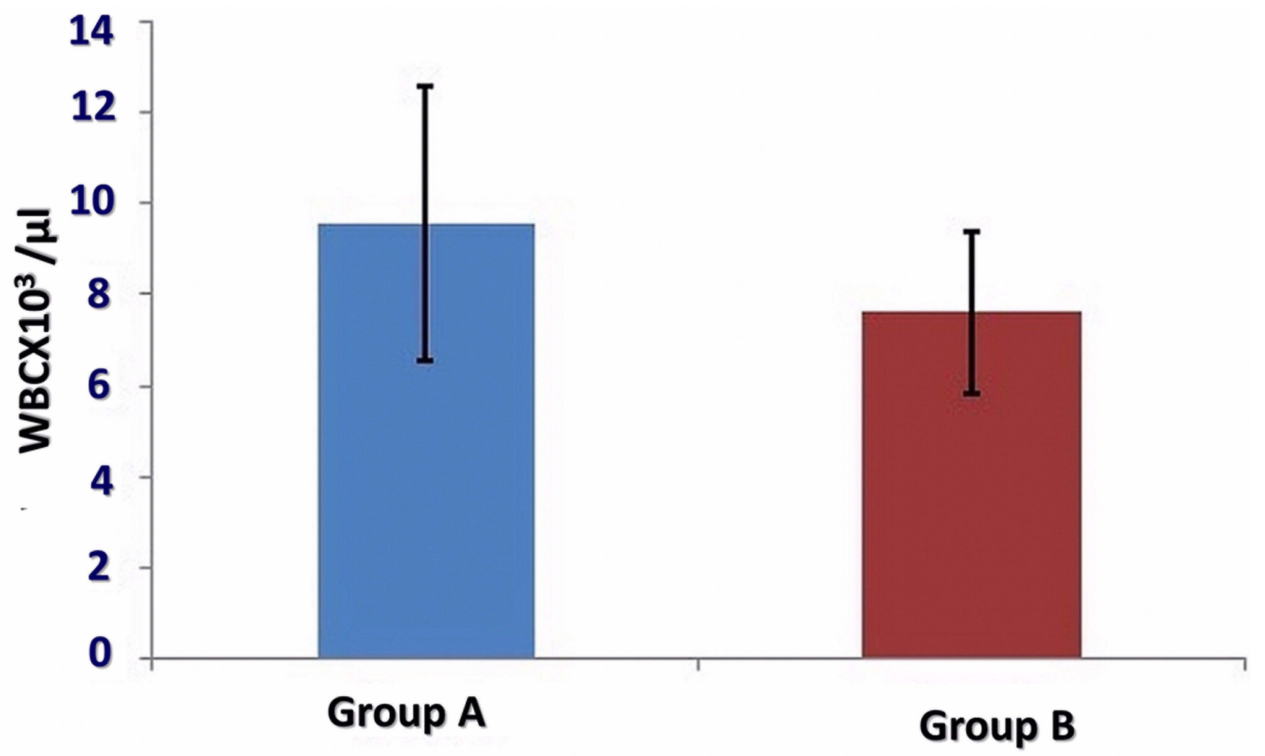

Figure 9 Mean total WBC count in both groups $(\mathrm{N}=92)$. Group A: cement dust-exposed recruits. Group B: healthy cement dust unexposed recruits (control). N= total number of recruits.

management practices that include monitoring and controlling of toxic agent's exposure risk at work and proper execution of health inspection. Trained professionals measure exposure and health inspection. Personal Protective equipment includes an FFP2 respirator mask and other protective gear. Surveillance of health include taking a medical history, performing spirometry (FVC, $\mathrm{FEV}_{1}$ ), Thorax inspection, percussion, and auscultation. ${ }^{7,75}$
CEMBUREAU, a representative organization for the European cement industry, has adopted policies to safeguard its labor force's health and safety. They have a "Zero harm" policy that ensures the cement industry regularly promotes health and safety practices; supervises thorough health and safety standards implementation; informs employees regarding work-related risk, provides proper personal protective equipment and training; performs regular surveillance of employees' health. They also have various campaigns such 
Table 7 Differential Count of WBC of the Cement Dust Exposed Recruits and Those Unexposed to Cement Dust

\begin{tabular}{|l|c|c|c|}
\hline Parameters & $\begin{array}{c}\text { Cement } \\
\text { Dust } \\
\text { Exposed } \\
\text { Recruits }\end{array}$ & $\begin{array}{c}\text { Cement Dust } \\
\text { Unexposed } \\
\text { Recruits(Control) }\end{array}$ & p value \\
\hline Neutrophil (\%) & $56.78 \pm 7.81$ & $55.24 \pm 11.61$ & $\mathrm{NS}$ \\
\hline Lymphocyte (\%) & $41.08 \pm 10.50$ & $35.60 \pm 7.11$ & $0.009 * *$ \\
\hline Monocyte (\%) & $3.98 \pm 2.00$ & $3.37 \pm 1.16$ & $\mathrm{NS}$ \\
\hline Eosinophil (\%) & $5.94 \pm 2.79$ & $4.21 \pm 2.11$ & $<0.001 * * *$ \\
\hline Basophil (\%) & $0.00 \pm 0.00$ & $0.00 \pm 0.00$ & \\
\hline
\end{tabular}

Notes: An Independent sample $t$-test was performed for statistical analysis to compare between the two groups; Mean \pm SE was used to express the data; **Significant; ***Highly Significant.

Abbreviation: NS, not significant; WBC, white blood cell.

as "Mate in Mind(UK)," "Safe Cement Campaign," "Cycle Safe" to create awareness among cement industry workers and the general population about health and safety at the workplace. $^{76}$

An International Cement company based in Heidelberg, Germany, ensures proper usage of Personal Protective gear, including a Safety Helmet, boots, and protection for the eye. They hold accountable their management for the workers' safety and health and emphasize that each employee follows work safety. ${ }^{77}$
The World Bank Group has Environmental, Health, and Safety Guidelines to be followed in projects in which the World Bank is involved. In the cement and lime manufacturing industry, this guideline includes methods to control and prevent dust exposure by avoiding the buildup of dust through vacuuming, usage of elevators with control of dust emission, usage of dust recycling and extraction system, usage of suction of air in area for bagging cement, use of proper mask, respirators. $^{78}$

\section{Limitations}

This study was a cross-sectional study in cement plant workers on a one-time point and may not represent the accurate risk estimation. The study was carried out under self-funding and therefore had financial limitations. Inflammatory markers like TNF alpha, proinflammatory cytokines (IL-1 $\beta$, IL-6, IL-8, IL-10, IL-12), and features of oxidative stress like reactive oxygen species, reactive nitrogen species, superoxide dismutase [SOD]), and nitrite $\left(\mathrm{NO}_{2}{ }^{-}\right)$could not be carried out due to time and financial constraint.

\section{Conclusions}

The results' analysis of this study shows that cement dust produces inflammatory responses in the exposed

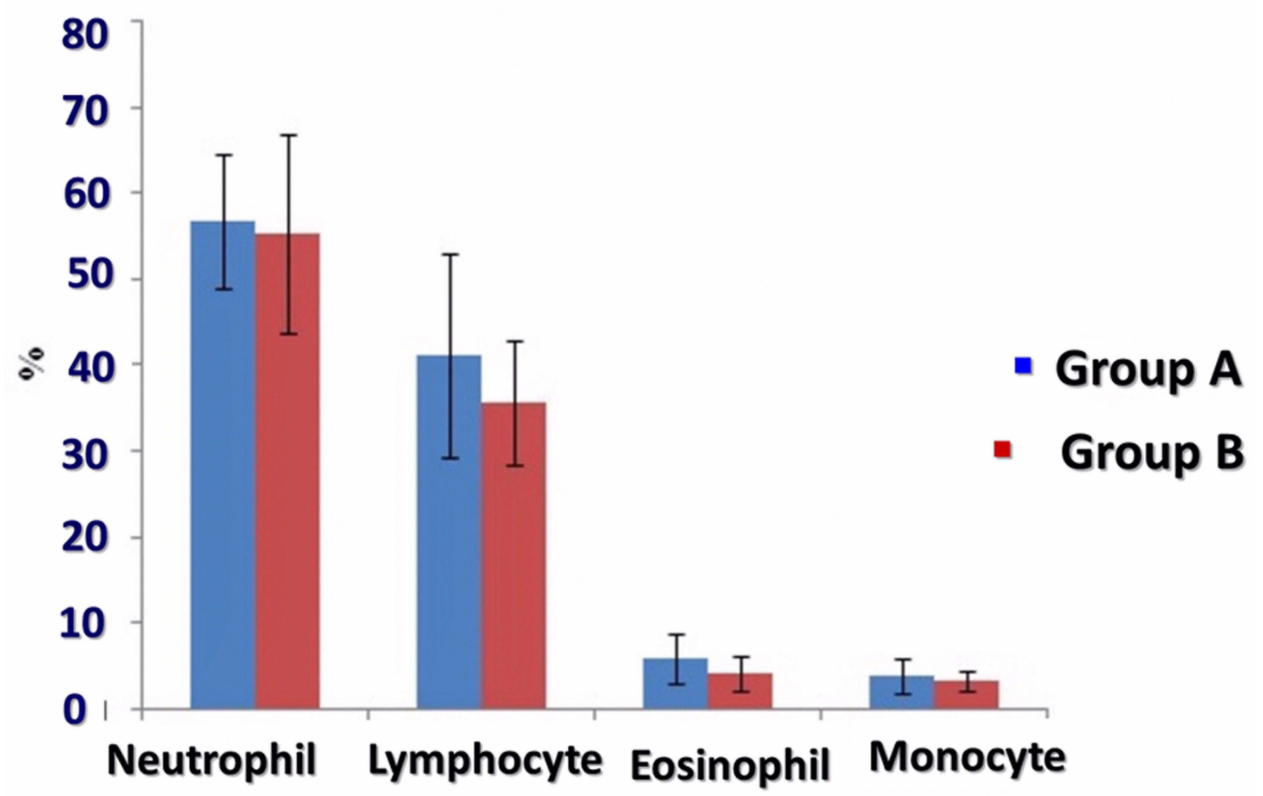

Figure 10 Mean differential counts in both groups ( $\mathrm{N}=92)$. Group A: cementdust-exposed recruits. Group B: healthy cement dust unexposed recruits (control). Abbreviation: $n$, number of study recruits. 
Table 8 Frequency and Percentage of Cement Dust Exposed Recruits Based on Total WBC Count and Duration of Cement Dust Exposure

\begin{tabular}{|l|c|c|}
\hline \multicolumn{2}{|l|}{ Parameters } & Case (\%) \\
\hline \multirow{2}{*}{ WBC count } & $<8 \times 10^{3} / \mu \mathrm{L}$ & $16(34.8 \%)$ \\
\cline { 2 - 3 } & $\geq 8 \times 10^{3} / \mu \mathrm{L}$ & $30(65.2 \%)$ \\
\hline \multirow{2}{*}{ Duration } & $\leq 5$ years & $16(34.8 \%)$ \\
\cline { 2 - 3 } & $>5$ years & $30(65.2 \%)$ \\
\hline
\end{tabular}

Notes: Data were expressed as frequency and percentage of WBC (white blood cells); the number of cement dust exposed recruits: 46 .

workers. This is evidenced by a significant increase in total WBC count, differential count of Lymphocyte and Eosinophil in cement dust exposed subjects. Multivariate Regression analysis revealed that the change in total WBC count is significantly related to the duration of cement dust exposure [OR $=4.42,95 \%$ CI $(1.56,12.47), p$ 0.005]. Additionally, univariate analysis revealed that the control group possessed less probability of total $\mathrm{WBC}$ count alteration (OR = $0.122,95 \% \mathrm{CI}=0.047$ to 0.311 ). The human hematopoietic system is sensitive to certain environmental factors as cells are rapidly synthesized and destroyed. This study's outcome reflects the inflammatory changes taking place in various body organs, such as the lungs, kidneys, liver of cement dust exposed subjects. Such inflammatory changes in multiple organs result from the toxic cement dust constituents like quartz, chromium, alumina, lead, nickel that may be inhaled,

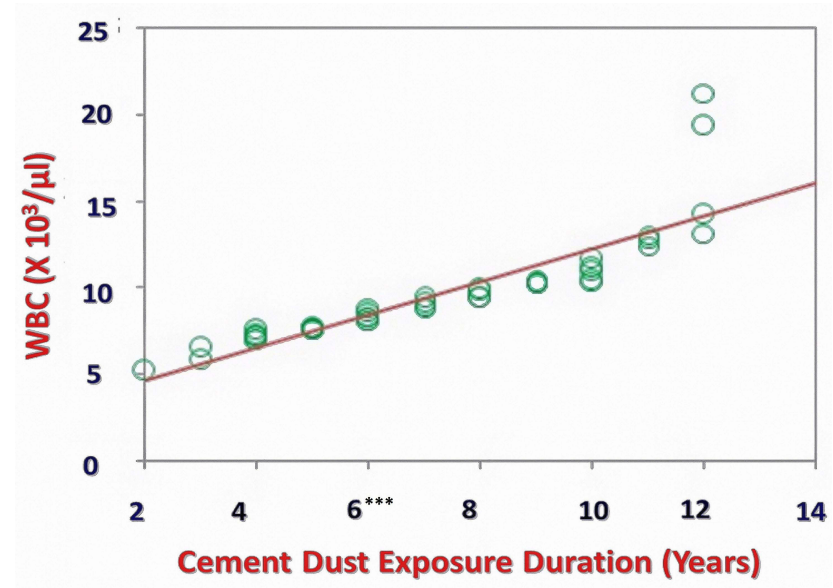

Figure I I Correlation of duration of cement dust exposure with the total count of WBC in the study group $(n=46)$. Study subjects: cement dust-exposed recruits. $r=$ $+0.872, p=<0.001 * * *$ [cement exposed group 6 years and onward were highly significantly positive $(p=<0.00 \mathrm{I})$ with changes regarding $\mathrm{WBC}]$.

Abbreviations: $N$, number of recruits in the study group; WBC, white blood cell. swallowed, and may penetrate through the skin. The observed deleterious changes suggest that those working in this toxic dusty environment are not taking adequate safety measures to minimize cement dust exposure. There may be a lack of proper understanding among the workers about the occupational health hazard. There may also be noncompliance among the workers regarding appropriate protective gear such as gloves, masks, helmets. Providing health education to workers, obtaining and enforcing effective protective equipment may limit this exposure to cement dust. Carrying out a blood test to monitor the inflammatory markers like the total count of WBC and its differentials may be a cost-effective and straightforward way for early detection of toxic changes in the organs of those occupationally exposed to cement dust. Thus, measures may be taken to prevent irreversible health damage in those occupationally exposed to cement dust.

About 60.8 million employed persons aged 15 years and above in Bangladesh, out of which 14.4\% are working in the manufacturing industry. ${ }^{79}$ The nonmetallic and gas industry that includes the cement industry, consists of about $8 \%$ of Bangladesh's total manufacturing sector. ${ }^{80}$ The cement industry, comprises 35 active companies and 42 cement plants across Bangladesh. ${ }^{81}$ There are another 0.2 and $5.6 \%$ of the labor force working in mining and quarrying sectors; construction, respectively. ${ }^{79}$ Mining and quarrying, an integral part of cement production and construction, have an environment polluted with cement dust or its toxic constituents. $^{82,83}$ This poses a threat to the health of its workers. Thus, national and company policies with guidelines to safeguard these workers' health must be implemented and monitored.

\section{Recommendations}

This study recommend that longitudinal studies on a more extensive study population be performed to estimate the actual health risk among the cement factory workers in Bangladesh. This research also suggest that studies on other inflammatory markers like pro-inflammatory cytokines and markers of oxidative stress be carried out to evaluate the extent of inflammatory damage in the occupational cement dust-exposed workers. Awareness and health education programs should be carried out among workers about the importance of using protective equipment such as gloves, masks, apparel. Usage of these protective gears needs to be enforced during the working 
Table 9 Association of Total WBC Count and Duration of Cement Dust Exposure in Cement Dust Exposed Recruits

\begin{tabular}{|l|c|c|c|c|}
\hline Effect & Odds Ratio (OR) & $\mathbf{9 5 \%}$ & Cl & P value \\
\hline WBC with duration & 4.42 & Upper Limit & Lower Limit & \\
\hline
\end{tabular}

Notes: Multivariate regression analysis was performed to observe the association between total WBC count and duration of cement dust exposure; significance level accepted for $\mathrm{p}<0.05$; the number of cement dust exposed recruits: 46 ; **Significant.

Abbreviation: WBC, white blood cells.

period. Technical protection measures should be adopted in collaboration with health-care providers, cement-exposed workers, and the cement factories' management team. We recommend implementing pre-employment and periodic medical examination of workers and environmental monitoring in these factories as part of a prevention program to safeguard the health of occupationally cement dust-exposed workers.

\section{Take-Home Message}

1. Cement industry is a fast-growing sector throughout the world and Bangladesh, but it is a source of pollution.

2. Cement dust containing toxic components like crystalline silica, chromium, nickel is released into the surrounding work environment during different of cement production and handling stages.

3. Workers in cement factories may inhale, ingest this dust, and toxic components of cement dust promote inflammatory response and tissue damage.

4. Raised total count of WBCs, Lymphocyte, and Eosinophil count observed in this study reflect the ongoing inflammatory changes in cement dustexposed subjects.

5. Monitoring the inflammatory markers like the total count of WBC and its differentials at a regular interval may be a simple and affordable means for early detection of inflammatory damage in workers exposed to the cement dust.

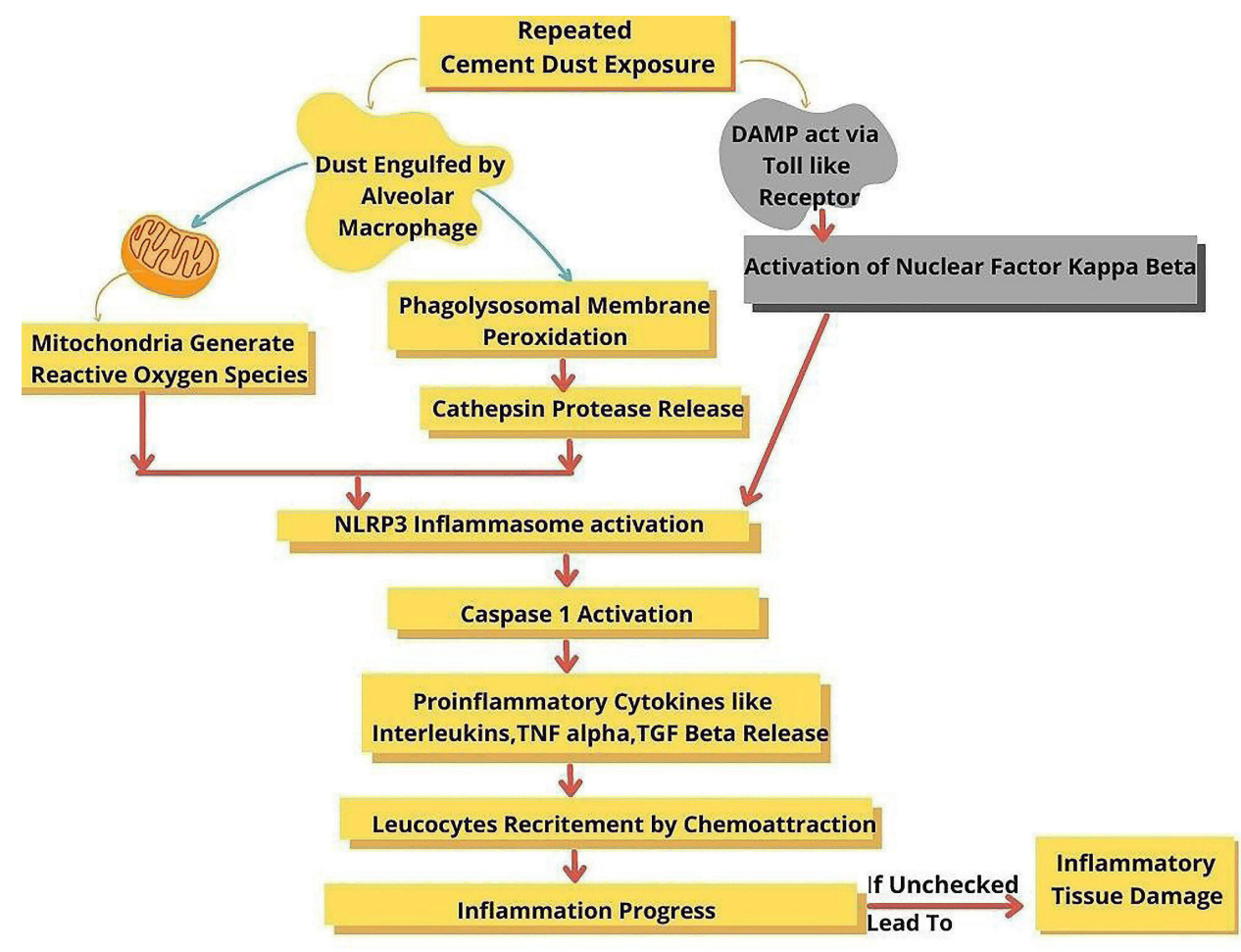

Figure 12 Possible mechanism of inflammatory response to cement dust. 


\section{Acknowledgment}

The authors thank the participants for cooperating during the study. The authors express their gratitude to Dr. Mahmuda Abira, Assistant Professor, Department of Physiology, 122 Kazi Nazrul Islam Avenue, Dhaka-1000, Bangladesh, for her kind effort and time regarding statistical analysis and interpretation.

\section{Authorship Contribution}

A significant contribution was made by all authors to the reported study, including concept creation, designing and executing of research, data acquisition, and interpreting of data following analysis; they participated in making the draft, revising, or reviewing the article critically; provided final approval of the version to be published; have come to the agreement on the journal to which the article has been submitted; and agreed to be accountable for all aspects of the work. Consent for Publication: The final version has been reviewed and approved by all authors. They have agreed to be responsible for all aspects of the work, including any issues related to accuracy or integrity.

\section{Funding}

This study was done through self-funding.

\section{Disclosure}

The authors and declaration report no conflicts of interest for this work because they have no affiliation or involvement with any organization financially or association of any entity directly or indirectly with the subject matter or materials that this article presents. This includes expert testimony, honoraria, stocks or options ownership, employment, royalties, grants, or patents received or pending.

\section{References}

1. LightCastle Partners. Bangladesh cement industry: optimistic despite challenges; 2020. Available from: https://www.lightcastlebd.com/ insights/2020/10/bangladesh-cement-industry-optimistic-despitechallenges. Accessed March 17, 2021.

2. Uddin MT, Chowdhury IM Sustainable development of concrete construction materials in Bangladesh. Bangladesh: 1st IUT International Seminar on Sustainability, Recycling, and Durability of Concrete Department of Civil and Environmental Engineering, Islamic University of Technology (IUT); 2014. Available from https://www. researchgate.net/publication/280572414_Sustainable_Development of_Concrete_Construction_Materials_in_Bangladesh. Accessed March 17, 2021.

3. Eastern Bank Limited Securities Limited. Cement industries of Bangladesh; 2019. Available from: http://www.eblsecurities.com/ AM_Resources/AM_ResearchReports/SectorReport/Comprehensive\% 20Review\%20on\%20Bangladesh\%20Cement\%20Industry,\%20August \%202019.pdf. Accessed March 17, 2021.
4. Zainudeen N. Cement and its effect to the environment: a case study in Sri Lanka. Available from https://www.irbnet.de/daten/iconda/ CIB11336.pdf. Accessed March 17, 2021.

5. Gupta RK, Majumdar D, Trivedi JV, Bhanarkar AD. Particulate matter and elemental emissions from a cement kiln Author links open overlay panel. Fuel Process Technol. 2012;104:343-351. doi:10.1016/j.fuproc.2012.06.007

6. Mousavi Z, Zarandi SM, Jozi SA, Khorasani N. Assessment of particulate matter (PM) emitted by cement industry: a case study in Shahroud. Res J Environ Sci. 2014;8:155-160. doi:10.3923/ rjes.2014.155.160

7. World Health Organization. Global health risks. Mortality and burden of disease attributable to selected major risks. Switzerland: WHO Press, World Health Organization; 2009. Available from: https:// www.who.int/healthinfo/global_burden_disease/GlobalHealthRisks_ report_full.pdf. Accessed March 17, 2021.

8. GBD 2016 Occupational Chronic Respiratory Risk Factors Collaborators. Global and regional burden of chronic respiratory disease in 2016 arising from non-infectious airborne occupational exposures: a systematic analysis for the Global Burden of Disease Study 2016. Occup Environ Med. 2020;77(3):142-150. doi:10.1136/ oemed-2019-106013

9. Dunuweera SP, Rajapakse MG. Cement types, composition, uses and advantages of nano cement, environmental impact on cement production, and possible solutions. Adv Mater Sci Eng. 2018;2018:1-11. doi: $10.1155 / 2018 / 4158682$

10. Richard EE, Augusta Chinyere NA, Jeremaiah OS, Opara UC, Henrieta EM, Ifunanya ED. Cement dust exposure and perturbations in some elements and lung and liver functions of cement factory workers. $J$ Toxicol. 2016;2016:6104719. doi:10.1155/2016/6104719

11. Erhabor O, Kebbe BI, Isaac IZ, et al. Effect of occupational exposure of cement dust on some hematological parameters of workers in a cement company in Sokoto, Nigeria. Int J Med Sci Health Care. 2013;1(7):21-25.

12. Manjula R, Parveena R, Rashmi RC, Ghattargi CH, Dorle AS, Lalitha DH. Effects of occupational dust exposure on the health status of Portland cement factory workers. Int J Med Public Health. 2013;3 (3):192-196. doi:10.4103/2230-8598.118963

13. Moncement project environmental impact studies. Mongolia: Monpolymet LLC; 2013. Available from: https://www.adb.org/sites/ default/files/project-document/76884/47908-014-mon-eia.pdf. Accessed March 17, 2021.

14. Industrial Minerals Association Europe. Respirable crystalline silica. Brussels: Industrial Minerals Association Europe; 2014. Available from: https://www.ima-europe.eu/eu-policy/productstewardship/respirable-crystallinesilica\#: :text=Crystalline $\%$ 20 silica $\% 20$ is $\% 20$ one $\% 20$ of, found $\% 20 \mathrm{in} \% 20$ nature $\% 20$ as $\%$ 20sand. Accessed February 14, 2018.

15. Institution of Occupational Safety and Health Administration. Let's talk dust: engagement discussion: facilitator notes. Washington, DC, USA: Occupational Safety and Health Administration; 2016. Available from: https://safety.networkrail.co.uk/wp-content/uploads/ 2016/07/Silica-Engagement-Discussion-Facilitator-notes.pdf. Accessed February 14, 2021.

16. Occupational Safety and Health Administration. Silica, crystalline. Washington, DC, USA: Occupational Safety and Health Administration; 2016. Available from: https://www.osha.gov/silicacrystalline/background-info. Accessed March 2, 2018.

17. Murugadoss S, Lison D, Godderis L, et al. Toxicology of silica nanoparticles: an update. Arch Toxicol. 2017;91(9):2967-3010. doi:10.1007/s00204-017-1993-y

18. Mayeux JM, Escalante GM, Christy JM, Pawar RD, Kono DH, Pollard KM. Silicosis and silica-induced autoimmunity in the diversity outbred mouse. Front Immunol. 2018;9:874. doi:10.3389/ fimmu.2018.00874 
19. National Center for Biotechnology Information. Compound summary for CID 23976, chromium. PubChem; 2021. Available from: https:// pubchem.ncbi.nlm.nih.gov/compound/Chromium. Accessed March $17,2021$.

20. Office of Environmental Health Hazard Assessment. Health effects of hexavalent chromium A fact sheet by CalEPA's office of environmental health hazard assessment November 9, 2016. Sacramento, USA: Office of Environmental Health Hazard Assessment; 2016. Available from: https://oehha.ca.gov/media/downloads/faqs/hexchro miumairfact111616.pdf. Accessed March 14, 2018.

21. Sun H, Brocato J, Costa M. Oral chromium exposure and toxicity. Curr Environ Health Rep. 2015;2(3):295-303. doi:10.1007/s40572015-0054-z

22. Estokova A, Palascakova L, Kanuchova M. Study on Cr(VI) leaching from cement and cement composites. Int J Environ Res Public Health. 2018;15(4):824. doi:10.3390/ijerph15040824

23. Yaman B. Health effects of chromium and its concentrations in cereal foods together with sulfur. Expo Health. 2020;12:153-161. doi:10.1007/s12403-019-00298-9

24. Sazakli E, Villanueva CM, Kogevinas M, Maltezis K, Mouzaki A, Leotsinidis M. Chromium in drinking water: association with biomarkers of exposure and effect. Int J Environ Res Public Health. 2014;11:10125-10145. doi:10.3390/ijerph111010125

25. Abdelhamid A. Effect of exposure to Portland cement dust on the periodontal status and on the outcome of non-surgical periodontal therapy. Int J Health Sci. 2016;10(3):339-352.

26. Zhang Y, Li C, Li S, et al. Dihydrotanshinone I alleviates crystalline silica-induced pulmonary inflammation by regulation of the Th immune response and inhibition of STAT1/STAT3. Mediators Inflamm. 2019;2019:3427053. doi:10.1155/2019/3427053

27. Odo RI, Mbegbu EC, Nwosu KC, et al. Effect of cement dust on reproductive performance and some physiological parameters in albino rats. Comp Clin Pathol. 2015;24(3):521-526. doi:10.1007/ s00580-014-1934-6

28. Wang S, Song R, Wang Z, Jing Z, Wang S, Ma J. S100A8/A9 in Inflammation. Front Immunol. 2018;9:1298. doi:10.3389/ fimmu.2018.01298

29. Chen L, Deng $\mathrm{H}$, Cui $\mathrm{H}$, et al. Inflammatory responses and inflammation-associated diseases in organs. Oncotarget. 2017;9 (6):7204-7218. doi:10.18632/oncotarget.23208

30. Gudkov AV, Komarova EA. p53 and the carcinogenicity of chronic inflammation. Cold Spring Harb Perspect Med. 2016;6(11):a026161. doi:10.1101/cshperspect.a026161

31. Czerkies M, Kwiatkowska K. Toll-like receptors and their contribution to innate immunity: focus on TLR4 activation by lipopolysaccharide. Adv Cell Biol. 2014;4:1-23. doi:10.2478/abc2014-0001

32. Mudaliar H, Pollock C, Komala MG, Chadban S, Wu H, Panchapakesan U. The role of Toll-like receptor proteins (TLR) 2 and 4 in mediating inflammation in proximal tubules. Am J Physiol Renal Physiol. 2013;305(2):F143-154. doi:10.1152/ ajprenal.00398.2012

33. Liu T, Zhang L, Joo D, Sun SC. NF-кB signaling in inflammation. Signal Transduct Target Ther. 2017;2:17023. doi:10.1038/ sigtrans.2017.23

34. Rodríguez-Hernández H, Simental-Mendía LE, Rodríguez-Ramírez G, Reyes-Romero MA. Obesity and inflammation: epidemiology, risk factors, and markers of inflammation. Int $J$ Endocrinol. 2013;2013:678159. doi:10.1155/2013/678159

35. Fox P, Hudson M, Brown C, et al. Markers of systemic inflammation predict survival in patients with advanced renal cell cancer. $\mathrm{Br}$ J Cancer. 2013;109(1):147-153. doi:10.1038/bjc.2013.300

36. Villeneuve DL, Landesmann B, Allavena P, et al. Representing the process of inflammation as key events in adverse outcome pathways. Toxicol Sci. 2018;163(2):346-352. doi:10.1093/toxsci/kfy047
37. Ogunbileje JO, Akinosun OM. Biochemical and hematological profile in Nigerian cement factory workers. Res $J$ Environ Toxicol. 2011;5(2):133-140. doi:10.3923/rjet.2011.133.140

38. Jaishankar M, Tseten T, Anbalagan N, Mathew BB, Beeregowda KN. Toxicity, mechanism, and health effects of some heavy metals. Interdiscip Toxicol. 2014;7(2):60-72. doi:10.2478/intox-2014-0009

39. Wilbur S, Abadin H, Fay M, et al. Toxicological profile for chromium. Atlanta, Georgia, USA: Agency for Toxic Substances and Disease Registry (US); 2012. Available from: https:/www.ncbi. nlm.nih.gov/books/NBK158855/pdf/Bookshelf_NBK158855.pdf. Accessed March 12, 2021.

40. Zeleke ZK, Moen BE, Bråtveit M. Cement dust exposure and acute lung function: a cross shift study. BMC Pulm Med. 2010;10:19. doi:10.1186/1471-2466-10-19

41. Gizaw Z, Yifred B, Tadesse T. Chronic respiratory symptoms and associated factors among cement factory workers in Dejen town, Amhara regional state, Ethiopia, 2015. Multidiscip Respir Med. 2016;11:13. doi:10.1186/s40248-016-0043-6

42. Meo SA, Al-Drees AM, Al Masri AA, Al Rouq F, Azeem MA. Effect of duration of exposure to cement dust on respiratory function of non-smoking cement mill workers. Int J Environ Res Public Health. 2013;10(1):390-398. doi:10.3390/ijerph10010390

43. Merenu IA, Mojiminiyi FBO, Njoku CH, Ibrahim MTO. The effect of chronic cement dust exposure on lung function of cement factory workers in Sokoto, Nigeria. Afr J Biomed Res. 2007;10:139-143.

44. Hommi BS, Abdelaziz MS, Ahmed HG. Effect of occupational cement dust pollution on the respiratory epithelium in Amran cement factory-Yemen. J Sci Tech. 2013;15:25-32.

45. Mbelambela EP, Eitoku M, Muchanga SMJ, et al. Prevalence of chronic obstructive pulmonary disease (COPD) among Congolese cement workers exposed to cement dust in Kongo Central Province. Environ Sci Pollut Res Int. 2018;25(35):35074-35083. doi:10.1007/ s11356-018-3401-4

46. Machowska A, Carrero JJ, Lindholm B, Stenvinkel P. Therapeutics targeting persistent inflammation in chronic kidney disease. Transl Res. 2016;167(1):204-213. doi:10.1016/j.trs1.2015.06.012

47. Watson J, Round A, Hamilton W. Raised inflammatory markers. BMJ. 2012;344:e454. doi:10.1136/bmj.e454

48. Farheen A, Hazari MAH, Khatoon F, Sultana F, Qudsiya SM. Hematological parameters are acutely effected by cement dust exposure in construction workers. Ann Med Physiol. 2017;1(1):31-35. doi:10.23921/amp.2017v1i1.263312

49. Guguloth MR, Sambanaik A, Srinivasnaik L, Mude J. The effect of cement dust exposure on hematological parameters of cement factory workers in Nalgonda, Andhra Pradesh. Int J Adv Res Tech. 2012;1 (5):46-52.

50. Al Salhen KSA. Assessment of oxidative stress, Hematological, kidney, and liver function parameters of Libyan cement factory workers. $J \quad A m \quad S c i$ 2014;10(5):58-65. doi:10.13140/ RG.2.1.4017.8647

51. Emmanuel TF, Ibiam UA, Okaka ANC, Alabi OJ. Effects of cement dust on the hematological parameters in Obajana cement factory workers. Euro Sci J. 2015;11(27):256-266.

52. Occupational Safety and Health Administration. By standard/ 1910.134 App C - OSHA respirator medical evaluation questionnaire (mandatory). Washington, DC, USA: Occupational Safety and Health Administration; 2012. Available from: https://www.osha.gov/lawsregs/regulations/standardnumber/1910/1910.134AppC. Accessed February 2, 2018.

53. Occupational Safety and Health Administration. By standard/ 1910.1051 App F - medical questionnaires (non-mandatory). Washington, DC, USA: Occupational Safety and Health Administration; 2013. Available from: https://www.osha.gov/lawsregs/regulations/standardnumber/1910/1910.1051AppF. Accessed February 2, 2018. 
54. Ahmed B, Shiraji KH, Chowdhury MHK, Uddin MG, Islam SN, Hossain S. Socio-economic status of the patients with acute coronary syndrome: data from a district-level general hospital of Bangladesh. Cardiovasc J. 2017;10(1):17-20. doi:10.3329/cardio.v10i1.34357

55. Ahmad R, Akhter Q. Effects of exposure to cement dust on hemoglobin concentration and total count of RBC in cement factory workers. J Bang Society Physiol. 2018;13(2):68-72. doi:10.3329/ jbsp.v13i2.39480

56. Flora MS, Islam MS. Anemia in Bangladesh: a longstanding, preventable public health problem. Bang Med J. 2010;39(3).

57. Divya Priya S, Suja S. The effect of cement dust exposure on hematological and cytogenetic studies of cement workers. Res J Pharma Bio Chen Sci. 2012;3(1):615-620.

58. Salh DM, Mohammed SM, Salih LOH. Some biochemical and hematological parameters among petroleum and cement factory workers in city/kurdistan/Iraq. Chem Mater Res. 2014;6(8):29-32.

59. Okonkwo COJ, Ugwu CE, Anakor ACF, Dike CC, Nwobodo E. The effects of cement dust on hematological parameters of cement workers in Asaba, Delta State, Nigeria. J Environ Sci Toxicol Food Technol. 2015;9(1):5-8. doi:10.9790/2402-09130508

60. Mojiminiyi FBO, Merenu IA, Njoku CH, Ibrahim MTO. Regression formulae for predicting hematologic and liver functions from years of exposure to cement dust in cement factory workers in Sokoto, Nigeria. African J Biomed Res. 2007;10(3):235-240.

61. Mandal MA, Suva P. Hematological changes among construction workers exposed to cement dust in West Bengal India. Prog Health Sci. 2014;4(1):88-94.

62. Pollard KM. Silica, silicosis, and autoimmunity. Front Immunol. 2016;7:97. doi:10.3389/fimmu.2016.00097

63. Dai W, Liu F, Li C, et al. Blockade of $\mathrm{Wnt} / \beta$-catenin pathway aggravated silica-induced lung inflammation through Tregs regulation on Th immune responses. Med Inflam. 2016;2016:6235614. doi:10.1155/2016/6235614

64. Mischler SE, Cauda EG, Giuseppe MD, et al. Differential activation of RAW 264.7 macrophages by size-segregated crystalline silica. J Occup Med Toxicol. 2016;11:57. doi:10.1186/s12995-016-0145-2

65. Rathinam VA, Vanaja SK, Fitzgerald KA. Regulation of inflammasome signaling. Nat Immunol. 2012;13(4):333-342. doi:10.1038/ ni.2237

66. Peeters PM, Eurlings IM, Perkins TN, et al. NLRP3 inflammasome activation in vitro and in rat lungs. Part Fiber Toxicol. 2014;11:58. doi:10.1186/s12989-014-0058-0

67. Tsui JCC, Law PTW, So WKW, et al. Short research communication regulation of TLR4 in silica-induced inflammation: an underlying mechanism of silicosis. Int $J$ Med Sci. 2018;15(10):986-991. doi:10.7150/ijms. 24715

68. Tolinggi S, Nakoe MR, Gobel IA, et al. Effect inhaling of limestone dust exposure on increased level of IL-8 serum and pulmonary function decline to workers of limestone mining industry. Int Refereed J Eng Sci. 2014;3(8):66-72.

69. Matsuzaki H, Hayashi H, Lee S, et al. Alteration of immune cells in silicosis: roles in development of autoimmunity and lung fibrosis. Ann Mens Health Wellness. 2017;1(1):1002.

70. Lin S, Wu H, Wang C, Xiao Z, Xu F. Regulatory T Cells and Acute Lung Injury: cytokines, Uncontrolled Inflammation, and Therapeutic Implications. Front Immunol. 2018;9:1545. doi:10.3389/ fimmu.2018.01545

71. Abdelhamid H, Mohammed MN, Alrazig SA, et al. Assessment of allergy marker leucocyte (Eosinophil) count and other blood cell parameters among workers at Berber cement factory, Berber governorate, River Nile state, Sudan, 2017. Global J Med Res: C Microbiol Pathol. 2017;17(1):1-3.
72. Kurado E, Ozasa K, Temizoz B, et al. Inhaled fine particles induce alveolar macrophage death and interleukin-1a release to promote inducible bronchus-associated lymphoid tissue formation. Immunity. 2016;45:1299-1310. doi:10.1016/j.immuni.2016.11.010

73. Jacobson LS, Lima H, Goldberg MF, et al. Cathepsin-mediated necrosis controls the adaptive immune response by Th2 (T helper type 2)-associated adjuvants. J Biol Chem. 2013;288:7481-7491. doi:10.1074/jbc.M112.400655

74. Cement Sustainability Initiative (CSI). Health management handbook: addressing occupational exposures in the cement industry. Switzerland: World Business Council for Sustainable Development; 2015; Available from: https://docs.wbcsd.org/2015/10/CSI_Health_ Management_Handbook_Eng.pdf. Accessed March 9, 2021.

75. Cement Sustainability Initiative (CSI). Safety in the cement industry: guidelines for measuring and reporting. Switzerland: World Business Council for Sustainable Development; 2013. Available from: file:/// C:/Users/MEH/Downloads/CSI\%20health\%20and\%20safety\% 20reporting\%20guidelines_v4\%20(1).pdf. Accessed March 9, 2021.

76. Cembureau. Worker protection culture. Brussels: CEMBUREAU, The European Cement Association. 2020. Available from: https:// cembureau.eu/policy-focus/health-safety/worker-protection-culture/. Accessed March 8, 2021.

77. Heidelberg Cement. Occupational health \& safety policy. Heidelberg, Germany: Heidelberg Cement; 2015. Available from: https://www. heidelbergcement.com/en/occupational-health-and-safety. Accessed March 8, 2021.

78. International Finance Corporation. Environmental, health, and safety guidelines for cement and lime manufacturing. Washington, DC, USA: World Bank Group; 2018. Available from: https://www.ifc. org/wps/wcm/connect/52592e0e-8475-4231-ba50-aeeb432e8e3c /20180719-Draft+for+2nd+Consultation-Cement+Lime+Mnfg.pdf? MOD=AJPERES\&CVID=m18Xzc7. Accessed March 8, 2021.

79. Bangladesh Bureau of Statistics. Report on labor force survey (LFS) 2016-17. Dhaka: Bangladesh Bureau of Statistics (BBS) under statistics and information division Ministry of Planning; 2018. Available from: http://203.112.218.65:8008/WebTestApplication/userfiles/ Image/LatestReports/LFS_2016-17.pdf. Accessed March 8, 2021.

80. Paul U, Hasan M, Labib L, Roy N. Optimal design of hybrid microgrids for readymade garments industry of Bangladesh: a case study. 3rd International Conference on Electrical Information and Communication Technology (EICT); 2017; Institution of Electrical and Electronic Engineering(IEEE); Fulbarigate, Khulna 9203 Bangladesh. doi:10.1109/EICT.2017.8275208.

81. Cement Manufacturers Association. Cement industry. Dhaka: Bangladesh Cement Manufacturers Association(BCMA); 2020. Available from: http://www.bcma.com.bd/cementindustry\#overview. Accessed March 10, 2021.

82. Portland Cement Association. How cement is made. Skokie, Illinois, USA: Portland Cement Association, America's Cement Manufacturers; 2019. Available from: https://www.cement.org/ cement-concrete/how-cement-is-made. Accessed March 10, 2021.

83. Peters S, Thomassen Y, Fechter-Rink E, Kromhout H. Personal exposure to inhalable cement dust among construction workers. J Phys Conf Ser. 2009;151:012054. doi:10.1088/1742-6596/151/1/ 012054 


\section{Publish your work in this journal}

The Journal of Inflammation Research is an international, peerreviewed open-access journal that welcomes laboratory and clinical findings on the molecular basis, cell biology and pharmacology of inflammation including original research, reviews, symposium reports, hypothesis formation and commentaries on: acute/chronic inflammation; mediators of inflammation; cellular processes; molecular mechanisms; pharmacology and novel anti-inflammatory drugs; clinical conditions involving inflammation. The manuscript management system is completely online and includes a very quick and fair peerreview system. Visit http://www.dovepress.com/testimonials.php to read real quotes from published authors. 